\title{
Palaeoenvironmental reconstruction and sequence stratigraphy of the Lower Cretaceous deposits in the Zagros belt, SW Iran
}

\author{
Reconstrucción paleoambiental y estratigrafía secuencial de los depósitos del Cretácico Inferior \\ en el cinturón de Zagros, SW Irán
}

Seyed Mohammad Ali Moosavizadeh ${ }^{1}$, Hamed Zand-Moghadam², Amir Hossein Rahiminejad,"*

${ }^{1}$ Department of Geology, Faculty of Sciences, Yazd University, University Blvd, 98195741, Safayieh, Yazd, Iran.

${ }^{2}$ Department of Geology, Faculty of Sciences, Shahid Bahonar University of Kerman, 7616913439, Kerman, Iran.

${ }^{3}$ Department of Ecology, Institute of Science and High Technology and Environmental Sciences, Graduate University of Advanced Technology, 7631818356, Kerman, Iran.

* Corresponding author: (A. H. Rahiminejad) mrrahiminejad7@gmail.com

How to cite this article:

Moosavizadeh, S. M. A., Zand - Moghadam, H.,Rahiminejad, A.H., 2020,Palaeoenvironmental reconstruction and sequence stratigraphy of the Lower Cretaceous deposits in the Zagros belt, SW Iran: Boletín de la Sociedad Geológica Mexicana, 72 (2), A060919. http:// dx.doi.org/10.18268/BSGM2020v72n2a060919

Manuscript received: February 28, 2019 Corrected manuscript received: August 10, 2019 Manuscript accepted: September 03, 2019

Peer Reviewing under the responsibility of Universidad Nacional Autónoma de México.

\begin{abstract}
Depositional environments and sequence stratigraphy of the Lower Cretaceous deposits of the Dariyan Formation were studied in the Zagros belt, SW Iran. The Dariyan Formation was investigated in the Interior Fars and the Izeh Zone in the SE margin of the Kazhdumi intra-shelf Basin, which has not been previously studied. Based on the benthic foraminifera, the Dariyan Formation is early Aptian to early Albian in age. The studies show that the Dariyan Formation was deposited in deep open-marine, shallow open-marine, shoal, and lagoonal settings on a homoclinal ramp. Three third-order depositional sequences (Ds1, Ds2, and Ds3) and three type 2 sequence boundaries (SB2) were recognized. The depositional sequences in the Dariyan Formation comprise three transgressive systems tracts (TSTs) and two highstand systems tracts (HSTs). During sea-level rise in the earliest Aptian, the Dariyan Formation was deposited on top of the the Barremian Gadvan Formation. Deep open-marine subsidence and sea-level rise led to deposition of radiolarian-bearing facies of the Dariyan Formation during the earliest Aptian. Subsequently, HSTs resulted in deposition of orbitolinid-rich facies in the deep open-marine setting (late early Aptian). Planktic foraminifera-bearing deposits were deposited during the subsequent sea-level rise (early late Aptian). Sea-level fall subsequently resulted in progradation of platform top (shallow open-marine, shoal, and lagoon) deposits into the deep open-marine setting (latest Aptian). Finally, sea-level rise resulted in deposition of the Albian Kazhdumi Formation on the Dariyan Formation during the early Albian. The sea-level changes recorded for the Dariyan Formation are consistent with Early Cretaceous sea-level patterns recognized elsewhere on the Arabian Plate.
\end{abstract}

Keywords: Facies, sequence stratigraphy, Dariyan Formation, AptianAlbian, Zagros fold-thrust belt.

\section{RESUMEN}

Este estudio representa los aspectos paleoambientales y la estratigrafia secuencial de la Formación Dariyan del Cretácico Inferior en el cinturón de Zagros, SW Irán. Se midió la formación en el Interior de Fars y la Zona de Izeh en el margen SE de la cuenca intra-plataforma de Kazhdumi la cual no se habia estudiado previamente. Basado en los foraminíferos bentónicos identificados, la Formación Dariyan tiene una edad de Aptiano temprano-Albiano temprano. Los estudios muestran que la Formación Dariyan se depositó en entornos de mar abierto profundo, mar abierto poco profundo, barra de arena y laguna en una rampa homoclinal. Se determinaron tres secuencias deposicionales de tercer orden (Ds1, Ds2 y Ds3) y tres límites de secuencia tipo 2 (SB2) en la formación. Las secuencias deposicionales en la Formación Dariyan comprenden tres tramos de sistemas transgresivos (TST) y dos tramos de soporte vertical (HST). Durante el aumento del nivel del mar en el Aptiano más temprano, la Formación Dariyan se depositó en la Formación Barremian Gadvan. La subsidencia en mar abierto profundo y el aumento del nivel del mar condujeron a la formación de facies portadoras de radiolarios en la Formación Dariyan durante el Aptiano más temprano. Posteriormente, el HST resultó en la deposición de facies ricas en orbitolinidos en el entorno marino abierto profundo (Aptiano temprano tardio). Se asentaron depósitos de foraminíferos pláncticos durante el posterior aumento del nivel del mar (Aptiano tardío temprano). Posteriormente, la caída del nivel del mar resultó en la progradación de depósitos (marinos abiertos poco profundos, de barrera de arena y de laguna) en la plataforma superior en el entorno marino abierto profundo (Aptiano tardio). Finalmente, el aumento del nivel del mar resultó en la depositación de la Formación Albiana Kazhdumi en la Formación Dariyan en el Albiano temprano. Los cambios en el nivel del mar registrados para la Formación Dariyan en este estudio son consistentes con los cambios en el nivel del mar del Cretácico temprano en la Placa de Arabia.

Palabras clave: Facies, estratigrafía secuencial, Formación Dariyan, AptianoAlbiano, Cinturón de pliegues y cabalgaduras Zagros. 


\section{Introduction}

The Zagros fold-thrust belt in southwestern Iran is characterized by sedimentary deposits ranging in age from the late Precambrian (Hormoz Salt Formation) to the present (James and Wynd, 1965; Setudehnia, 1978; Berberian and King, 1981).

The Lower Cretaceous Dariyan Formation in the Zagros belt represents one of the most important carbonate reservoirs in the northeastern margin of the Arabian Plate and the Middle East (Persian Gulf, formerly southwest of the Neo-Tethys Ocean; Figure 1) (Al-Husseini and Matthews, 2010; Rahmani et al., 2010; Mansouri-Daneshvar et al., 2015). Following sea-level rise, the Dariyan Formation was deposited during the Aptian-Albian (Sharland et al., 2001; Ziegler, 2001; Alavi, 2004, 2007; Schroeder et al., 2010) in the uppermost part of the Upper Jurassic to the Lower Cretaceous Khami Group (James and Wynd, 1965; Mansouri-Daneshvar et al., 2015), between the older Gadvan and the younger Kazhdumi shale-dominated formations (Sharland et al., 2001; Van Buchem et al., 2010) (Figure 2).

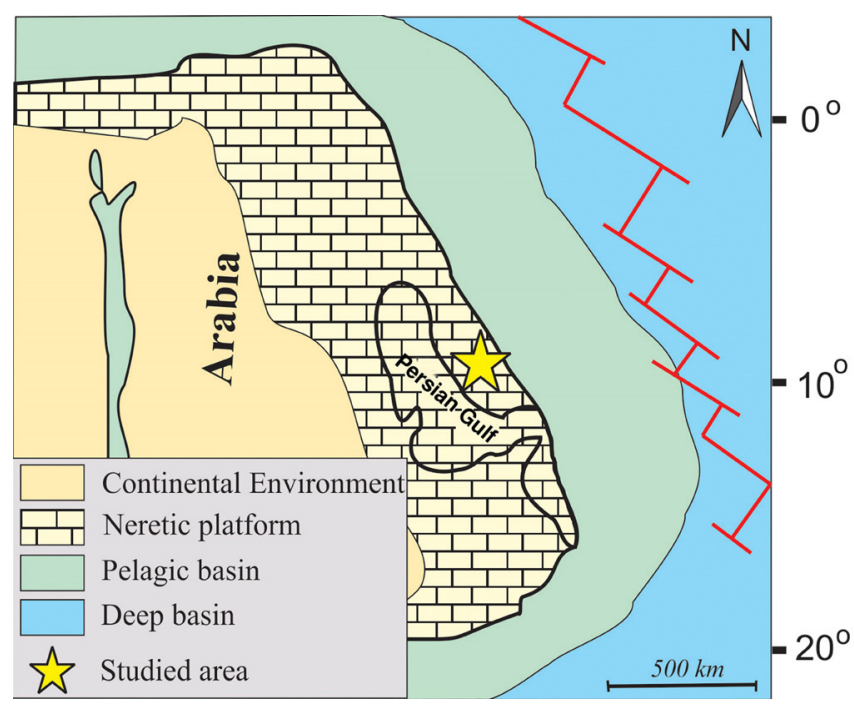

Figure 1 Location of the Arabian plate during the Aptian (after Huck et al., 2010, 2011). The studied area is located in the northeastern margin of the Arabian Plate and the Middle East and was formerly situatd in southwest of the Neo-Tethys Ocean (Al-Husseini and Matthews, 2010; Rahmani et al., 2010; MansouriDaneshvar et al., 2015). The present day locations of the Persian Gulf Region and the studied area are shown on the map.
The Dariyan Formation corresponds to foraminiferal biozones 16, 17, and 18 of Wynd (1965). In this paper, our focus is on the south-eastern margin of the Kazhdumi Intra-shelf Basin in the Zagros belt. Previous studies of this part of Iran are scarce to absent.

The aim of this study was to investigate the depositional model and the sequence stratigraphic architecture of the Dariyan Formation in the Zagros belt. By doing so, this paper contributes to a better understanding of relative sea-level changes during the Early Cretaceous and shed light on the deposition of Lower Cretaceous carbonates in the Zagros belt.

Results presented herein are relevant from a local and regional Early Cretaceous perspective and, more generally, contribute to palaeogeographical reconstructions of the Zagros belt and petroleum exploration in this region.

\section{Geological setting and location of the studied area}

The studied area lies in the structural zones of Izeh (the Izeh Zone) and the Interior Fars Province in the Zagros fold-thrust belt, southwestern Iran (Figure 3). The Zagros fold-thrust belt is about $2000 \mathrm{~km}$ long and resulted from the Arabia-Eurasian collision (Beydoun et al., 1992; Alavi, 2004; Fakhari et al., 2008). This belt is a part of the Alpine-Himalayan orogenic belt and extends in a NW-SE trend from the East Anatolian fault in eastern Turkey to the south of Iran and into Oman (Alavi, 2004). The evolutionary and depositional trends of the sedimentary successions in the Zagros belt record the geology and palaeoceangraphy of the Cretaceous in the northeastern margin of the Arabian Plate (Sharland et al., 2001; Ziegler, 2001; Alavi, 2004, 2007).

The Zagros belt in the northeastern margin of the Gondwana Super continent migrated along a 'C'-shaped pathway between the latest Precambrian and the Present (Heydari, 2008). During this time, a 7 to $12 \mathrm{~km}$-thick succession of detrital, 
evaporitic, and carbonate rocks was deposited in what today form the Zagros Mountains (Heydari, 2008).

The deposition of the Aptian-Albian Dariyan Formation in the Zagros belt was synchronous with the development of extensive Tethyan carbonate platforms (Masse, 1993; Ziegler, 2001; Skelton et al., 2003). The Dariyan Formation was originally referred to as 'Orbitolina limestone' (James and Wynd, 1965) and generally consists of shallow-water limestones rich in orbitolinids and rudists (Van Buchem et al., 2010). The formation is locally divided into a lower and an upper unit separated by the informal 'Kazhdumi Tongue' unit (Sedaghat, 1982) consisting of planktic foraminifera-bearing shales and marls (Van Buchem et al., 2010). The Dariyan Formation conformably overlies the shale deposits of the Gadvan Formation with an isochronous boundary (James and Wynd, 1965; Schroeder et al., 2010; Van Buchem et al.,
2010) and is in turn conformably overlain by the Kazhdumi Formation with a diachronous contact (Schroeder et al., 2010) (James and Wynd, 1965; Motiei, 1993; Van Buchem et al., 2010). During the Early Cretaceous, regional depocenters (intrashelf basins) developed on the Arabian passive margin as a result of fault activation and/or salt diapir movements (Sharland et al., 2001; Van Buchem et al., 2010). The Kazhdumi intra-shelf Basin, one of these depocenters, resulted from the Kazerun and Hendijan strike-slip activities (Sharland et al., 2001; Van Buchem et al., 2010).

The studied area is located in the southeastern margin of the Kazhdumi intra-shelf Basin (Sharland et al., 2001). There, the Dariyan Formation was studied in three stratigraphic sections (Paskahak, Seydan, and Sangsiah; Figures 3 to 6). According to the structural subdivisions of the Zagros fold-thrust belt (Alavi, 2004, 2007), the Paskahak section $\left(30^{\circ} 17^{\prime} 08^{\prime \prime} \mathrm{N}, 51^{\circ} 30^{\prime} 12^{\prime \prime} \mathrm{E}\right)$ is

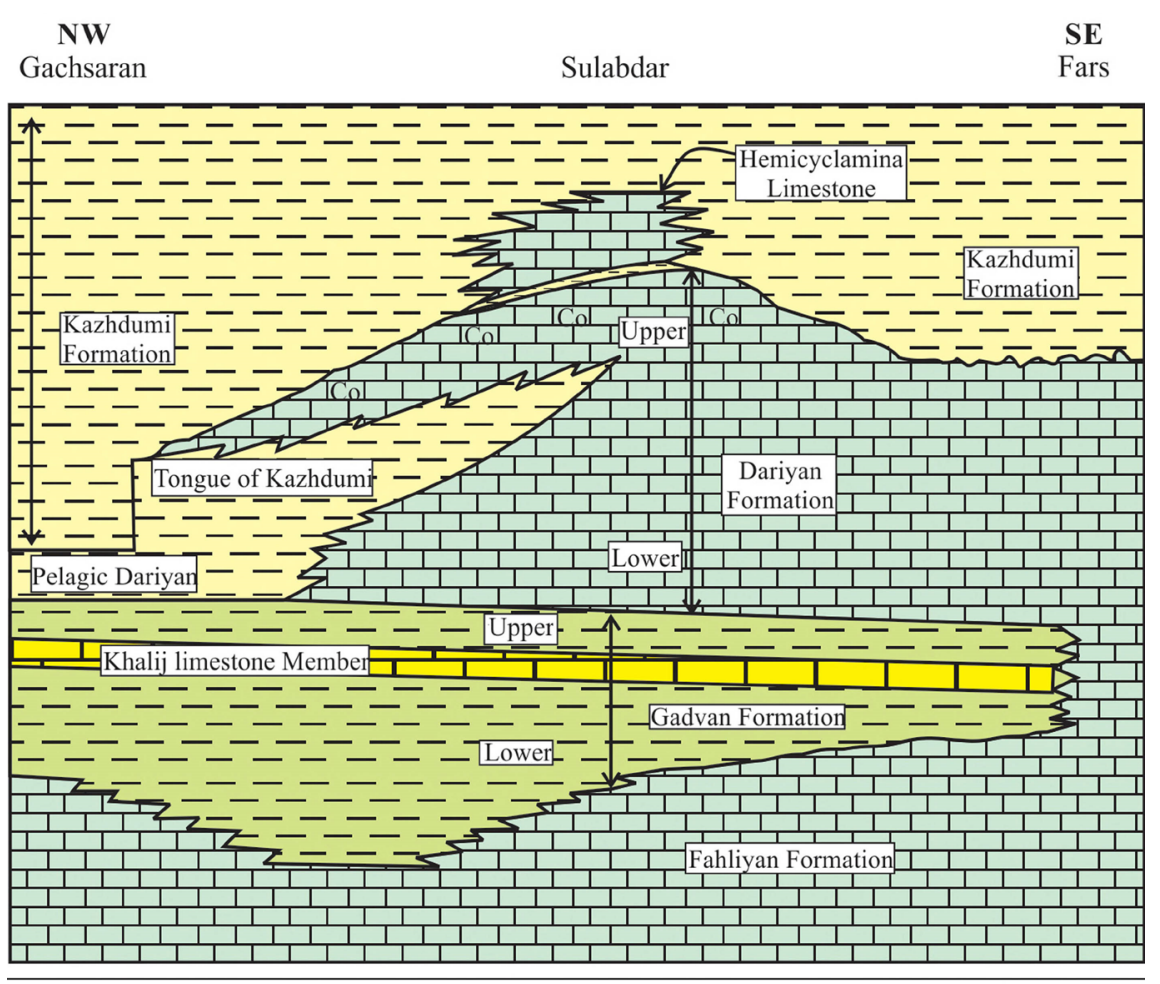

\section{Legend: Limestone}

Figure 2 Generalized stratigraphic section of the Barremian-Albian formations in the Zagros belt. The Dariyan Formation was deposited between the Gadvan and the Kazhdumi formations (simplified from Motiei, 1993). 
located in the Izeh Zone in about $17 \mathrm{~km}$ of west of the Kazerun fault. The Sangsiah $\left(30^{\circ} 05^{\prime} 37^{\prime}\right.$ N, $\left.53^{\circ} 08^{\prime} 23^{\prime \prime} \mathrm{E}\right)$ and Seydan (30 05' 19'N, 52 $56^{\circ}$ $\left.43^{\prime \prime} \mathrm{E}\right)$ sections are situated in the Interior Fars Province, east of the fault (Figure 3).

\section{Materials and methods}

The stratigraphic sections of the Dariyan Formation (Figures 3 to 6 ) were selected based on the geological maps of Fahliyan (McQuillin, 1974), Sivand (Yousefi and Kargar, 1999), and Saadat-Shahr (Kargar, 2002). Note that these sections allowed us to study the platform top and deep open-marine facies of the Dariyan Formation. A total of 395 rock samples (limestone, marl, and shale) were collected and classified based on the Grabau (1904) classification.

Uncovered thin sections were prepared for petrographic analyses. Facies types and benthic foraminifera were identified based on field observations and microscopic analyses of the thin sections. The thin-sections were analyzed with an Olympus polarizing microscope. The classification of the facies is according to Dunham (1962) and Embry and Klovan (1971). In order to distinguish calcite and dolomite, thin sections were stained following the approach of Dickson (1966). Based on this method, a solution was obtained by mixing $0.2 \mathrm{~g}$ of Alizarin Red S and $100 \mathrm{~mL}$ of hydrochloric acid $(1.5 \%)$. The uncovered thin sections were put in the solution for 20s. The calcite grains turned red, whereas the dolomite grains remained colourless.

Twenty-seven samples of the shales and marls were washed and sieved. Planktic foraminifera were separated using a binocular microscope and fossils documented under a scanning electron microscope. Standard facies models proposed by Burchette and Wright (1992) and Flügel (2010) were used for the depositional interpretation. Sequence-stratigraphy analyses were based on Catuneanu et al. (2009, 2011).

\section{Results}

The stratigraphic details of the Dariyan Formation in the three sections are shown in Figures 4 to 7.

\subsection{LITHOSTRATIGRAPHY}

The Dariyan Formation conformably overlies the Barremian Gadvan Formation and is in turn conformably overlain by the Albian Kazhdumi Formation in all studied sections (Figure 4 to 6).

In the Sangsiah section (Figures 4 and $7 \mathrm{~A}$ to 7D), the 230m thick Dariyan Formation is divided into three lithostratigraphic units: (i) The lower unit (65 m thick) consists of grey to light grey, thick-bedded limestones. Orbitolinids are scattered on the rock surface of the limestones. (ii) The middle unit (49 m thick) mainly comprises thin- to medium-bedded argillaceous limestones (containing discoidal orbitolinids) and intercalations of orbitolinid-bearing grey shales. (iii) The upper unit (116 m thick) consists of light-grey ooidal limestones. In the Sangsiah section, five thickening-upward cycles are present in the form of medium- to thickly-bedded limestones in the Dariyan Formation in the Sangsiah section (Figure 7B). Cross laminationated light-grey limestones and cross-bedding structures are typical for this section (Figure 7C and 7D).

Based on the presence of alternations of marl and shale in an interval (the Kazhdumi Tongue) in the middle part of the Dariyan Formation (Figures 5 and $7 \mathrm{E}$ to $7 \mathrm{I}$ ), in the Seydan section, this formation is divided into a lower unit (lower Dariyan), the Kazhdumi Tongue, and an upper unit (upper Dariyan). The lower unit, $37 \mathrm{~m}$ in thickness, is mainly composed of limestones, argillaceous limestones, and intercalations of shales and brown to black cherty bands. Shallowing-upward parasequences with flooding surfaces are present in the lower unit in the Seydan section (Figure 7G). Grain-size decreases upsection in a regionally important Exogyra marker shell bed (Figure 7I) in the lower unit in the Seydan and Paskahak sections 


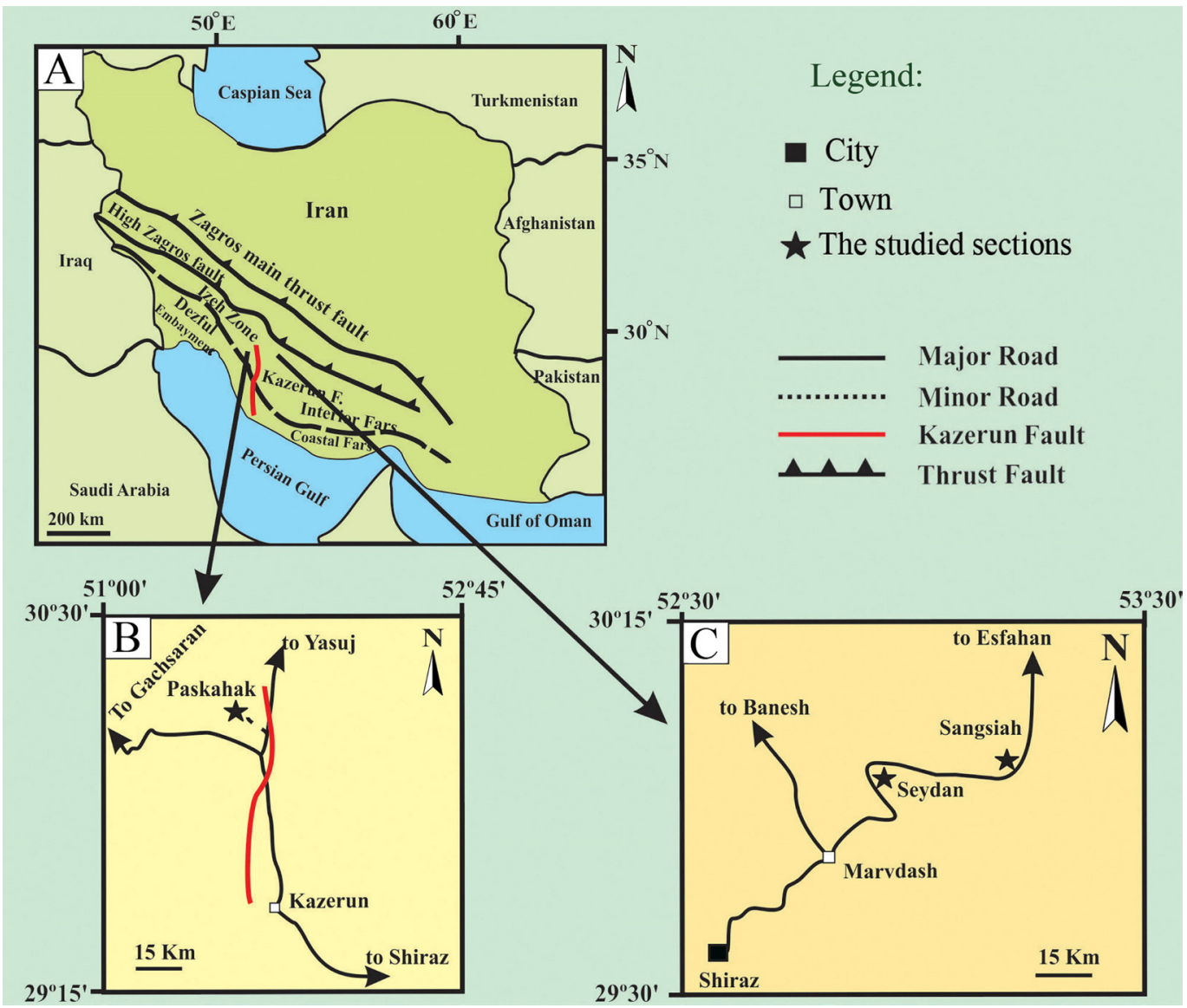

Figure 3 Localities of the studied sections of the Dariyan Formation in the Zagros fold-thrust belt, southwest Iran (modified from Habibi, 2016). The Sangsiah and Seydan sections are situated in the Interior Fars, whereas the Paskahak section is located in the Izeh Zone, west of the Kazerun fault. The Seydan section $\left(30^{\circ} 05^{\prime} 19^{\prime \prime} \mathrm{N}, 52^{\circ} 56^{\prime} 43^{\prime \prime} \mathrm{E}\right)$ was measured $65 \mathrm{~km}$ to the northeast of the city of Shiraz. The Sangsiah section $\left(30^{\circ} 05^{\prime} 37^{\prime \prime} \mathrm{N}, 53^{\circ} 08^{\prime} 23^{\prime \prime} \mathrm{E}\right)$ was measured $80 \mathrm{~km}$ northeast to the city of Shiraz and $24 \mathrm{~km}$ from the Seydan section. The Paskahak section $\left(30^{\circ} 17^{\prime} 08^{\prime \prime} \mathrm{N}, 51^{\circ} 30^{\prime} 12^{\prime \prime} \mathrm{E}\right)$ was measured $76 \mathrm{~km}$ northwest to the town of Kazerun.

(Figure 7H). Individual shells are commonly well preserved and only a limited number of fragmented shells are found. Note, intraclasts are absent and there is no clastic contact or boundary in the basal boundary of the bed.

In the uppermost part of the lower unit of the Dariyan Formation in the Seydan and Paskahak sections, ammonite external casts and horizontal laminations are present. The Kazhdumi Tongue (50 $\mathrm{m}$ thick) consists of alternations of grey shales and marls and few intercalations of argillaceous limestones. The shale deposits are rich in planktic foraminifera. The upper unit of the Dariyan Formation (Seydan section), is $133 \mathrm{~m}$ thick, comprises grey and dark-grey, medium- to thickly-bedded calcarenite and calcirudite limestones with conical and discoidal orbitolinids, bivalves (mainly rudists), and gastropods. In the Seydan section, bioturbation is a common feature in the uppermost parts of the upper Dariyan unit. (Figure 7F).

In the Paskahak section, the Dariyan Formation (Figures 6 and $7 \mathrm{H}$ to $7 \mathrm{~L}$ ) is divided into a lower unit (lower Dariyan), the Kazhdumi Tongue, and an upper unit (upper Dariyan). The lower unit (32 $\mathrm{m}$ thick), consists of thickly-bedded limestones with bivalve shells (mainly rudists), grey thin-bedded argillaceous limestones (with planktic foraminifera and ammonites) and intercalations of marls and shales. The Kazhdumi Tongue (68 $\mathrm{m}$ thick) is built by an alternation of marls and shales (in the Seydan section, shales are more abundant than in the Kazhdumi 
Tongue). The upper unit is $100 \mathrm{~m}$ thick and mainly comprises medium- to thickly-bedded, orbitolinid-bearing limestones. In the Paskahak section, limonitic bioturbations are present in the basal part of the lower unit of the Dariyan Formation (Figure 7K). Continuous and discontinuous silicified intercalations occur in the lower unit of the formation (Figure 7L).

\subsection{BIOSTRATIGRAPHY}

The biostratigraphic details of the Dariyan Formation as shown in the studied sections are documented in Figures 4 to 6 . The stratigraphic range of the identified benthic foraminifera suggests that the Dariyan Formation is early Aptian to early Albian in age (Boudagher-Fadel, 2008; Schroeder et al., 2010; Figures 4 to 6 and 8). The identified foraminifera (Figure 8) are: Choffatella decipiens, Archaealveolina sp., Palorbitolina lenticularis, Mesorbitolina parva, Mesorbitolina texana, Mesorbitolina subconcava, and Hemicyclammina sigali.

\subsection{FACIES}

Fifteen facies types were identified in the studied sections (Figures 4 to 6 and 9). These are described below:

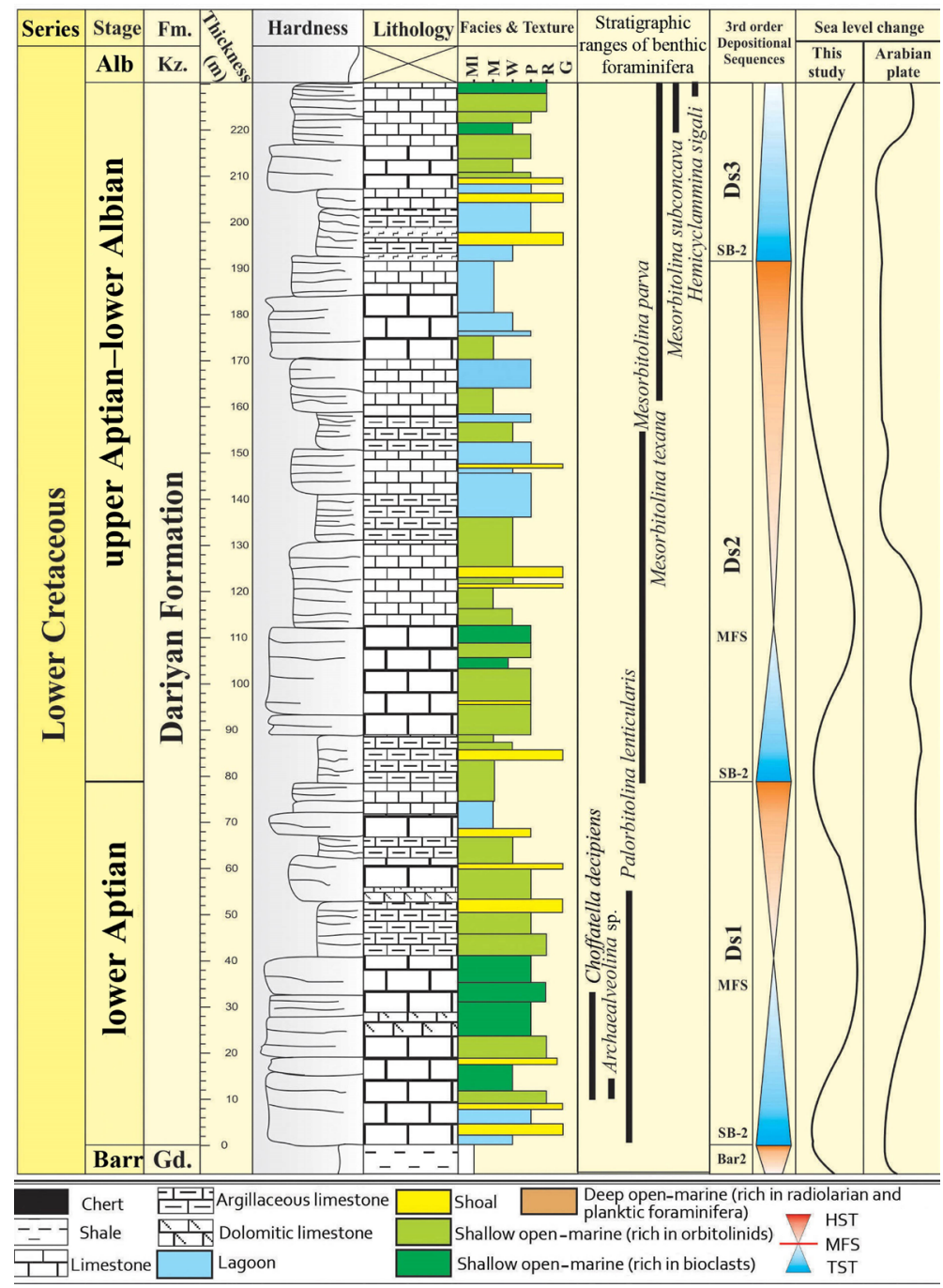

Figure 4 The stratigraphic column of the Dariyan Formation (230 m thick) in the Sangsiah section. Kz.: Kazhdumi Formation. Gd.: Gadvan Formation. MI: marl. M: mudstone. W: wackestone. P: packstone. R: rudstone. G: grainstone. Ds: depositional sequence. SB-2: type 2 sequence boundary. MFS: maximum flooding surface. HST: highstand systems tract. TST: transgressive systems tract. Barr: Barremian. Alb: Albian. Fm: Formation. The sea-level curve of the Arabian Plate is based on Van Buchem et al. (2010). 


\subsubsection{F1: SHALE}

Facies F1 consists of grey, green, and black shales. This facies is typical of the Kazhdumi Tongue and the upper part of the lower unit of the Dariyan Formation in the Seydan and Paskahak sections. The shales mainly contain planktic foraminifera (Figure 9A) and laterally grade into marls and argillaceous limestones.

\subsubsection{F2: MARL}

Facies F2 is typified by grey to dark-grey marls. Biota include planktic foraminifera and radiolarians.
Facies F2 is present in the Kazhdumi Tongue and the upper beds of the lower Dariyan unit in the Seydan and Paskahak sections (Figures 5 and 6).

\subsubsection{F3: RADIOLARIAN WACKESTONE/PACKSTONE}

Radiolarians are the dominant biota in facies F3 (Figure 9B and 9C). Radiolarian tests have a mean dimension of $0.03 \mathrm{~mm}$ and are commonly calcified. Other biota include planktic foraminifera, sponge spicules, and bioclasts such as thin bivalve shells in the form of filaments (Flügel, 2010). Moreover, facies F3 is rich in organic materials (Figure 9B). This facies is typical for the Seydan and Paskahak

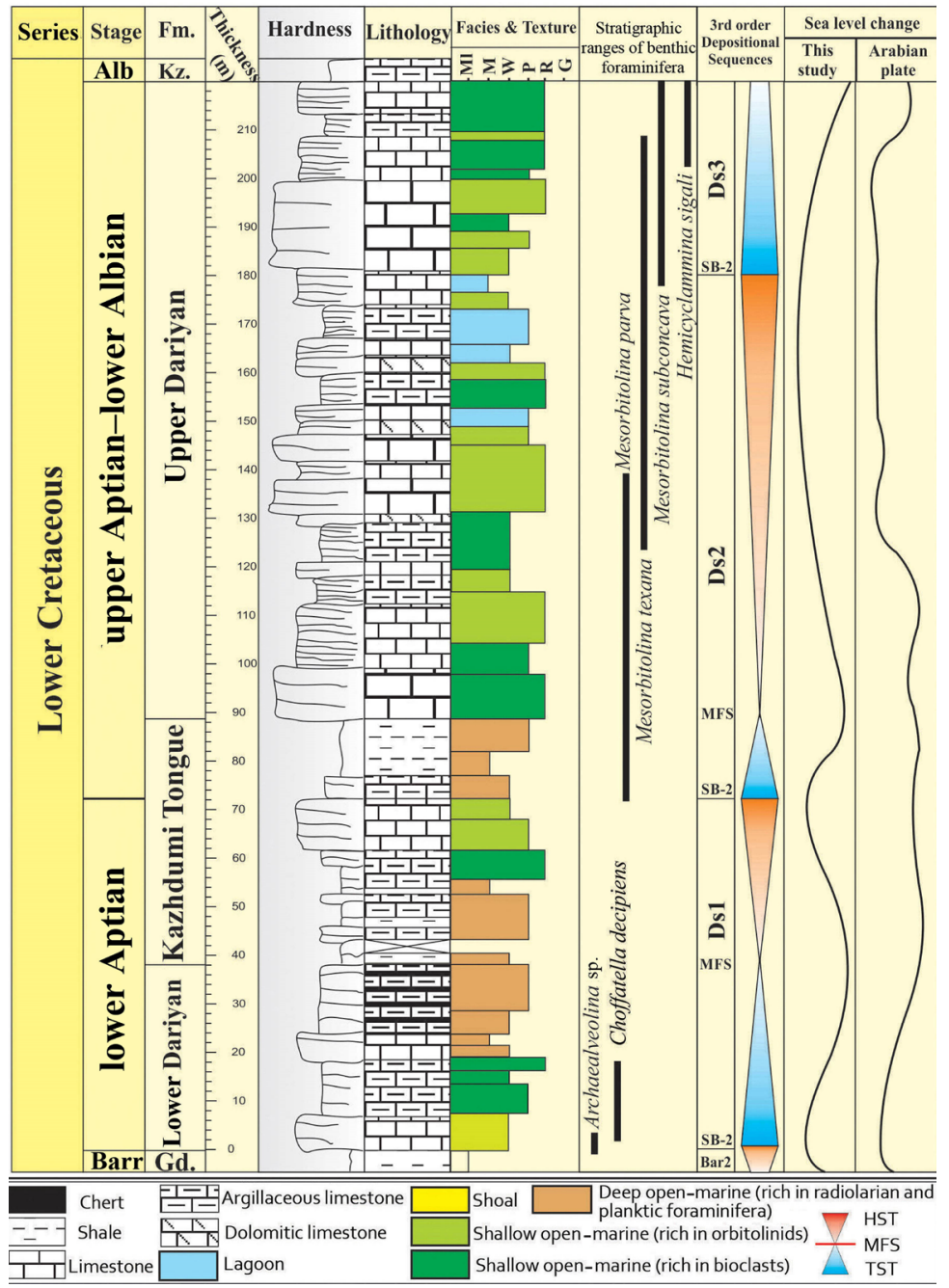

Figure 5 The stratigraphic column of the Dariyan Formation (220 m thick) in the Seydan section. Gd: Gadvan Formation. Kz: Kazhdumi Formation. MI: marl (marls and shales occur in the 'Kazhdumi Tongue' and the upper part of the lower unit of the Dariyan Formation). M: mudstone. W: wackestone. P: packstone. R: rudstone. G: grainstone. Ds: depositional sequence. SB-2: type 2 sequence boundary. MFS: maximum flooding surface. HST: highstand systems tract. TST: transgressive systems tract. Barr: Barremian.Alb: Albian. Fm: Formation. The sea-level curve of the Arabian Plate is based on Van Buchem et al. (2010). 
sections. The radiolarian wackestone/packstone facies crops out as limestones and thin-bedded argillaceous limestones $(10-50 \mathrm{~cm}$ thick). Horizontal laminations and ammonite external casts are common in the limestones. Facies F3 grades upsection into black cherts.

\subsubsection{F4: PLANKTIC FORAMINIFERA WACKESTONE/ PACKSTONE}

The main biota in facies F4 (Figure 9D) include planktic foraminifera hosted in a micritic matrix. Foraminifera tests range in size from 0.1 to 0.25 mm. Other biota, such as sponge spicules and radiolarians, are present but volumetrically less singificant. Abundant organic material is probably the reason for the dark weathering color of facies F4, and particularly so in the Paskahak section. Locally, red-brown oil staining is observed.

\subsubsection{F5: BIOCLASTIC WACKESTONE/PACKSTONE}

Facies F5 yields a diverse bioclastic assemblage (30-50\%) of bivalves (rudists and oysters), brachiopods, gastropods, and echinoid spines (Figure 9E) all embedded in a micritic matrix. Skeletal remains

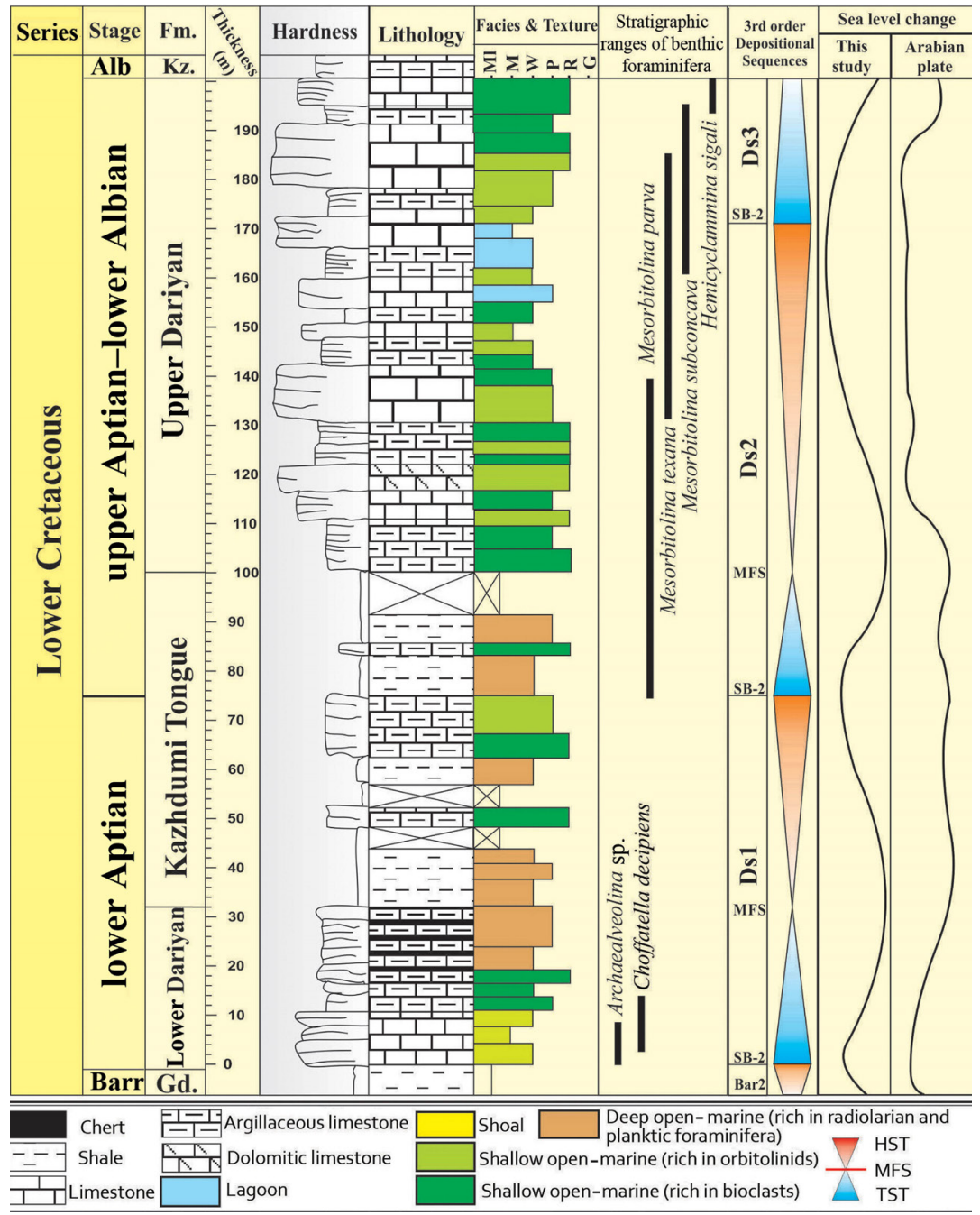

Figure 6 The stratigraphic column of the Dariyan Formation (200 m thick) in the Paskahak section. Gd: Gadvan Formation. Kz: Kazhdumi Formation. Ml: marl (marls and shales occur in the 'Kazhdumi Tongue' and the upper part of the lower unit of the Dariyan Formation). M: mudstone. W: wackestone. P: packstone. R: rudstone. G: grainstone. Ds: depositional sequence. SB-2: type 2 sequence boundary. MFS: maximum flooding surface. HST: highstand systems tract. TST: transgressive systems tract. Barr: Barremian. Alb: Albian. Fm: Formation. The sea-level curve of the Arabian Plate is based on Van Buchem et al. (2010). 
range in size from several microns to $5 \mathrm{~mm}$. Sparse discoidal orbitolinids are present but are volumetrically subordinate. Peloids $(10-12 \%)$ are rare.

\subsubsection{F6: BIOCLASTIC RUDSTONE}

Bivalve fragements and shells (rudist debris and oysters), gastropods, and crinoid ossicles are the dominant biota (about 3 to $4 \mathrm{~mm}$ in diameter) of facies F6 (Figure 9F). The abundance of skeletal grains larger than $2 \mathrm{~mm}$ is approximately 15 to $20 \%$. Bivalve remains (mainly rudists) that range in size from 10 to $15 \mathrm{~cm}$ occur in this facies. In the lower and middle parts of the lower unit of the Dariyan Formation, facies F6 crops out as grey and dark-grey, medium-bedded limestones. Accumulation of the remains of bivalves and crinoid ossciles (about $4 \mathrm{~cm}$ in size) locally form shell beds in the lower unit of the Dariyan Formation in the Seydan and Paskahak sections.

\subsubsection{F7: DISCOIDAL ORBITOLINID RUDSTONE}

Facies F7 (Figure 9G) is dominated by large discoidal orbitolinids $(\sim 3-4 \mathrm{~mm}$ in diameter). Subordinate biota include benthic foraminifera (such as textularids) and fragments of bivalves (rudists and oysters) and gastropods. Peloids are present in facies F7.

\subsubsection{F8: BIOCLASTIC GRAINSTONE}

Facies F8 is a cement-supported grainstone with abundant skeletal grains. These include: fragments of bivalves (mainly rudists), echinoids $(<1 \mathrm{~mm}$ in size), gastropods, and benthic foraminifera such as orbitolinids (Figure 9H). The size of the fragments of bivalves and gastropod shells reaches up to $4 \mathrm{~mm}$. Conical orbitolinids, with a relative abundance of $15 \%$, are also present in this grain-supported facies.

\subsubsection{F9: OOID GRAINSTONE}

Concentric ooids (0.7-1.2 mm) embedded in a sparry cement are the dominant (ca. 45\%) grains in facies F9 (Figure 9I). The nuclei of ooids include peloids, fragments of echinoid spines, bivalves (mainly rudists), and benthic foraminifera such as miliolids. Ooids with nuclei comprising bioclasts are larger in size $(\sim 1.5 \mathrm{~mm})$ and are elongated or ellipsoidal in shape. Peloids (up to $10 \%$ ), green algae $(\sim 5 \%)$ (yellow arrow in Figure $9 \mathrm{I}$ ), and benthic foraminifera such as textularids $(\sim 5-8 \%)$, represent subordinate grains. Facies F9 occurs in yellow, thin- and cross-bedded limestones.

\subsubsection{F10: PELOIDAL ORBITOLINID GRAINSTONE}

Facies F10 (Figure 9J) is dominated by conical orbitolinids ( $\sim 1.5 \mathrm{~mm}$ in size; $40 \%)$ embedded in a sparry cement. Peloidal grains $(\sim 15-20 \% ; 0.2$ $\mathrm{mm}$ in diameter) are well sorted and moderately rounded. Skeletal grains, such as benthic foraminifera (miliolids and textularids) $(\sim 8 \%)$, are less common. Facies F10 crops out in the form of grey, thinly-bedded limestones with cross-laminations.

\subsubsection{F11: PELOIDAL GRAINSTONE}

Peloids $(\sim 35 \%)$ in a sparry cement are the most common grains in facies F1 1 (Figure 9K). These grains range in size from 0.2 to $0.35 \mathrm{~mm}$ and are not well rounded. They are considered as lithic type peloids. Benthic foraminifera $(\sim 15 \%)$, such as miliolids, textularids, and Nezazzata, are the subordinate grains ( $\sim 0.5 \mathrm{~mm}$ in size). Facies F1 1 is less common in the studied sections and was only identified in a few beds in the Sangsiah section.

\subsubsection{F12: ORBITOLINID PACKSTONE}

Facies F12 is typified by its grain-supported texture and the predominance of orbitolinids. Orbitolinids (Figure 9L) are mostly $(\sim 40 \%)$ conical (with a length/height ratio of less than 1.5). They range in size from about 1.5 to $2 \mathrm{~mm}$. Subordinate grains $(\sim 10-15 \%)$ include other benthic foraminifera, such as miliolids and textularids as well as peloids. Facies F12 is one of the major carbonate facies of the Dariyan Formation and is present in the three studied stratigraphic sections. 

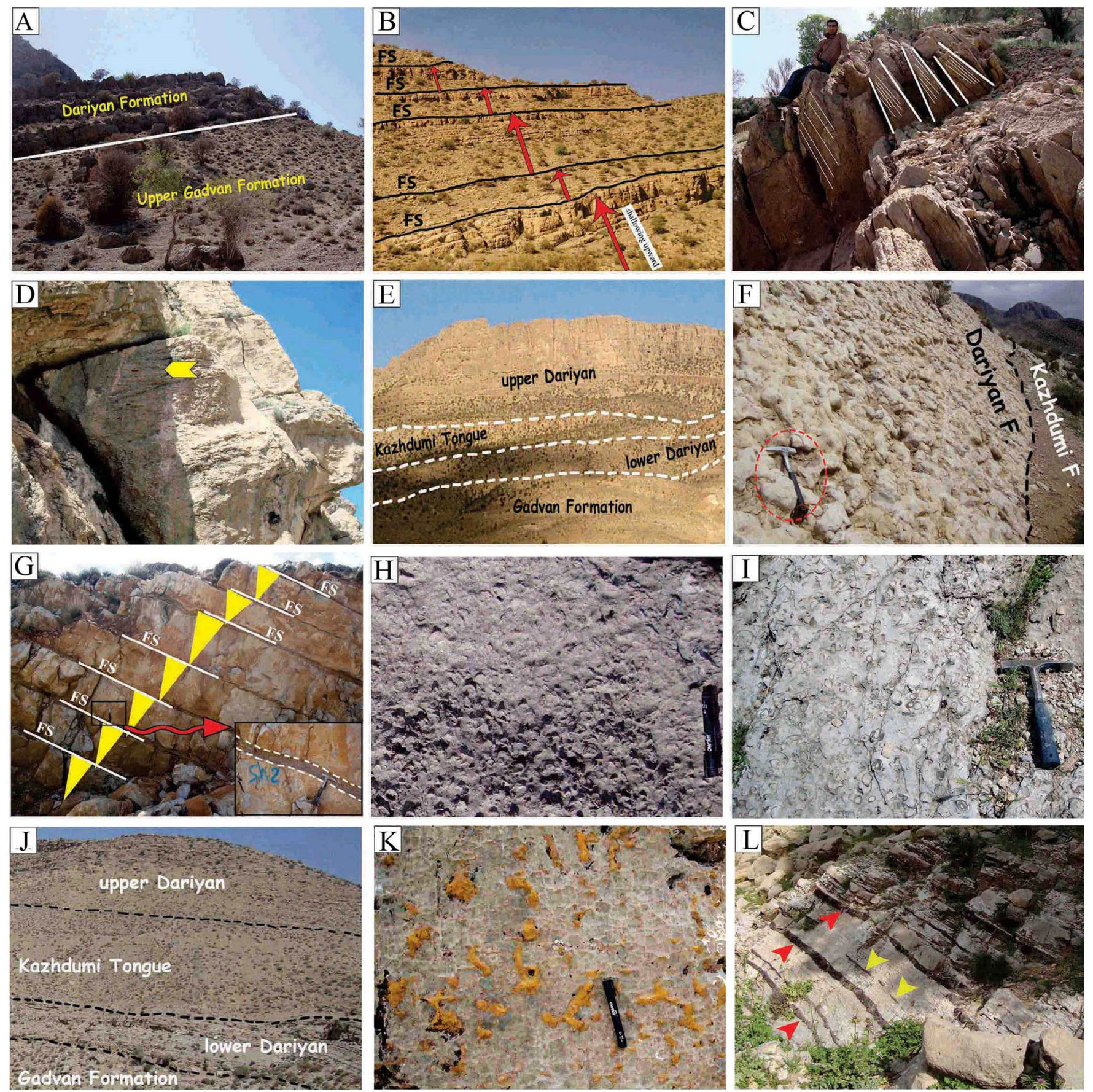

Figure 7 Outcrop images and details of the Dariyan Formation in the studied sections. (A) The lower or basal boundary of the formation in the Sangsiah section. (B) The five thickening upward cycles of the medium to thickly-bedded limestones in the Sangsiah section. (C) Cross-bedding in the Sangsiah section. (D) Cross lamination in light grey limestones in the Sangsiah section. (E) General view of Dariyan Formation in the Seydan section. (F) The top surface of the upper unit of the Dariyan Formation with largely distributed bioturbations in the Seydan section. (G) Shallowing-upward parasequences with flooding surface (FS) in the lower unit of the Dariyan Formation in the Seydan section. Red arrow and dotted lines: flooding surface. $(\mathrm{H})$ Grain-size decreases upsection in an Exogyra marker shell bed in the lower unit of the Dariyan Formation (in the Seydan and Paskahak sections). (I) Exogyra marker shell bed in the lower unit in the Seydan and Paskahak sections. (J) General view of the Dariyan Formation in the Paskahak section. (K) Limonitic bioturbations in the base of the lower unit of the Dariyan Formation in the Paskahak section. (L) Continuous (red arrows) and discontinuous (yellow arrows) silicified intercalations in the lower unit of the Dariyan Formation in the Paskahak section. 


\subsubsection{F13: PELOIDAL FORAMINIFERA WACKESTONE/ PACKSTONE}

The dominant grains in facies F13 (Figure 9M) include benthic foraminifera (miliolids and textularids) $(\sim 25 \%)$ and peloids $(\sim 15 \%)$. The grains are about $0.5 \mathrm{~mm}$ in size. Fragments of green algae are also present. Facies F13 is present in all studied sections. In outcrop, facies F 13 appears as grey to dark-grey, medium-bedded limestones.

\subsubsection{F14: PELOIDAL GREEN ALGAE WACKESTONE/ PACKSTONE}

Facies F14 is dominated by green algae $(\sim 20 \%)$ and peloids $(\sim 15 \%)$ (Figure $9 \mathrm{~N})$. Fragments and well-preserved specimens of Lithocodium aggregatum (yellow arrow in Figure 9N) are present. Facies F14 is typical in the Sangsiah section.

\subsubsection{F15: MILIOLID MUDSTONE}

Facies F15 predominantly consists of lime mud and yields a limited number of benthic foraminifera, such as miliolids $(\sim 8 \%)$, and rare fine-grained bioclasts such as bivalves and gastropods (Figure 9O). Facies F15 is present in all studied sections. This facies crops out as grey and dark-grey, medium-and thick-bedded limestones.

\section{Interpretation}

\subsection{DEPOSITIONAL ENVIRONMENTS}

Based on the standard facies models (e.g., Wilson, 1975; Read, 1985; Burchette and Wright, 1992; Flügel, 2010) and the identified facies in the Dariyan Formation, four depositional settings including deep open-marine, shallow open-marine, shoal, and lagoon were established (Figures 4 to 6, 9 and 10).

\subsubsection{DEEP OPEN-MARINE SETTING}

The occurrence of shales (facies F1) and marls (facies F2) and the horizontal laminations and muddy matrix reflect low-energy conditions (Bover-Arnal et al., 2009; Flügel, 2010). Additionally, the presence of biotic components, such as radiolarians and planktic foraminifera, and the absence of benthic and euphotic fauna in facies F1 though F4, indicate that deposition occurred under relatively low-energy conditions in a deep open-marine setting (Cosovic et al., 2004; Nichols, 2009; Bassi and Nebelsick, 2010; Payros et al., 2010). Moreover, high amounts of organic materials in the matrix (e.g., in the Paskahak section) might indicate oxygen depletion or deficiency in basinal water masses (Michalík et al., 2008; Stein et al., 2012).

\subsubsection{SHALLOW OPEN-MARINE SETTING}

The shallow open-marine setting is characterized by the three facies: F5, F6, and F7. Accumulation of large fossil shells (3 to $4 \mathrm{~mm}$ in size) is typical for these facies.

The presence of brachiopods, bivalves (mainly rudists), and echinoids reflects a normal marine salinity and open-marine conditions (Bachmann and Harisch, 2006; Flügel, 2010; Aghaei et al., 2019). Also, the occurrence of discoidal orbitolinids can indicate open-marine conditions (Pittet et al., 2002) with relatively low water energy (Schroeder et al., 2010; Rahiminejad and Hassani, 2016a, 2016b). The faunal assemblages in the shallow open-marine facies are generally indicative of the euphotic zone (Romero et al., 2002; Corda and Brandano, 2003; Cosovic et al., 2004).

The decreasing-upward grain size distribution in the Exogyra marker shell bed of the lower unit of the Dariyan Formation (in the Seydan and Paskahak sections) (Figure $7 \mathrm{H}$ ) can be representative of transport and redeposition of the components or grains (Pérez-López and Pérez-Valera, 2012; Rubert et al., 2012) and also moderate water energy resulting from intermittent wave energy and/or currents (Bover-Arnal et al., 2009). These sedimentary conditions reflect deposition below the fair-weather wave base and above the storm wave base (Corda and Brandano, 2003; Bover-Arnal et al., 2009; Bassi and Nebelsick, 2010). 
12 / Boletín de la Sociedad Geológica Mexicana / 72 (2) / 2020
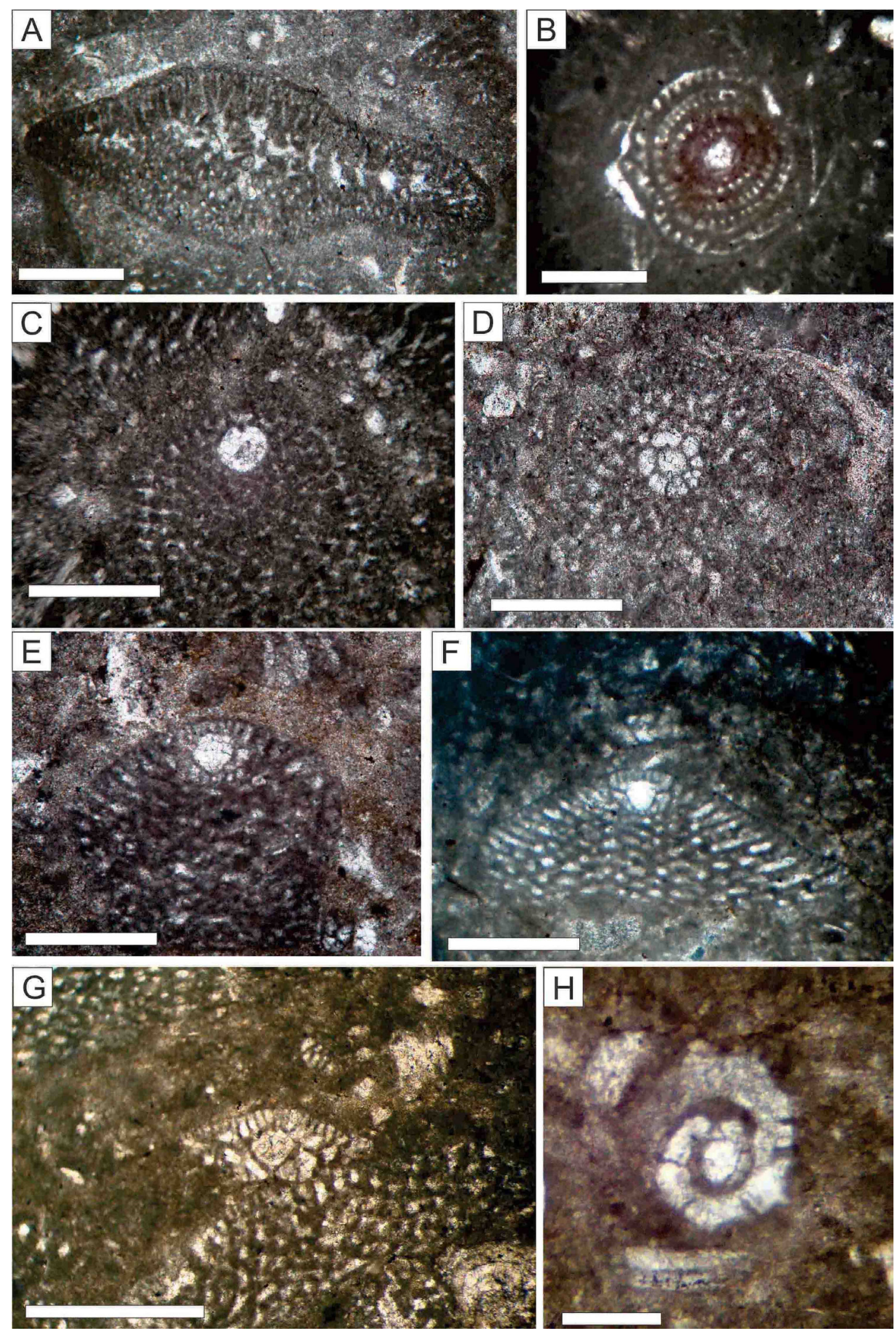

Figure 8 Thin section images (PPL) of the benthic foraminifera used in the biostratigraphy of the Lower Cretaceous deposits in this study. Scale bar: $0.5 \mathrm{~mm}$. (A) Choffatella decipiens. (B) Archaealveolina sp. (C) Palorbitolina lenticularis. (D) Mesorbitolina parva, transversal section. (E) Mesorbitolina parva, axial section. (F) Mesorbitolina texana. (G) Mesorbitolina subconcava. (H) Hemicyclammina sigali. 

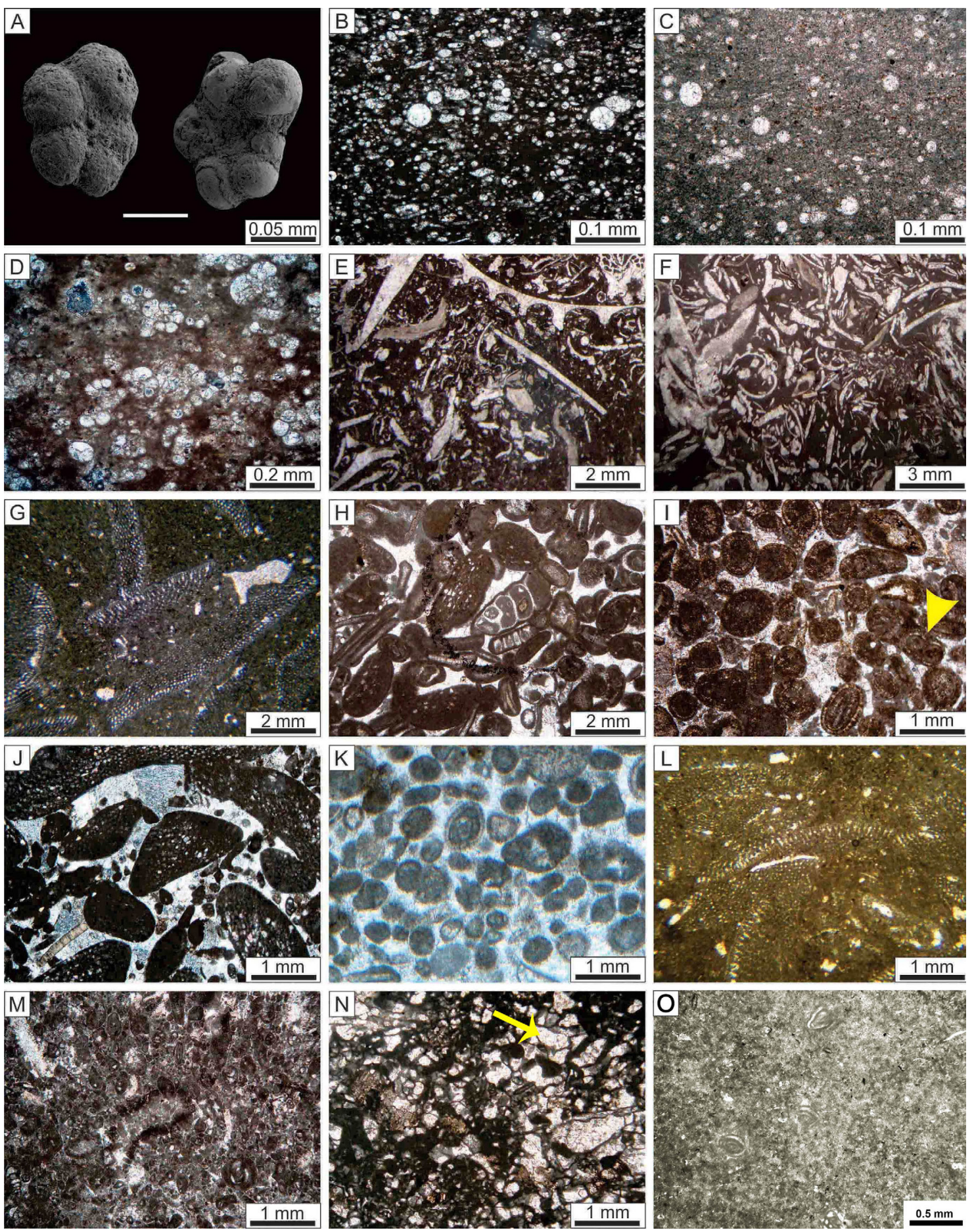

Figure 9 Thin section images of the facies in the studied Cretaceous deposits. Images B, D and L: XPL. Other images: PPL. (A) Planktic foraminifera in the shales and marls of the 'Kazhdumi Tongue' (the Paskahak and Seydan sections). (B) Radiolarian packstone with a lime-mud matrix containing organic matter (F3) (the Paskahak section). (C) Radiolarian wackestone with a lime-mud matrix (F3) (the Paskahak section). (D) Planktic foraminifera packstone with organic matter in the matrix (F4) (the Seydan section). (A-D: deep open-marine.) (E) Bioclastic packstone with bivalve shells (F5) (the Seydan section). (F) Bioclastic rudstone with poorly rounded grains (F6) (the Sangsiah section). (G) Discoidal orbitolinid rudstone (F7) (the Sangsiah section). (E-G: shallow open-marine.) (H) Bioclastic grainstone (F8). Small size orbitolinids, gastropods, and bivalve debris are present in the facies. Micrite envelope edge is clear around the components (the Sangsiah section). (I) Ooid grainstone (F9) in cross-bedded limestones (the Sangsiah section). Green algae is indicated by yellow arrow. (J) Peloidal orbitolinid grainstone. The facies contains conical to discoidal orbitolinids and peloids. The grains in the facies have been rounded as a result of agitation (F10) (the Sangsiah section). (K) Well-sorted peloidal grainstone; small benthic foraminifera are subordinate. Size and shape of peloides reflect lithic origin for these grains (F11) (H-K: shoal). (L) Orbitolinid packstone (F12) (the Sangsiah section). The facies contains conical orbitolinids. (M) Peloidal foraminifera packstone with milliolid benthic foraminifera (F13) (the Sangsiah section). (N) Peloidal green algae wackestone/packstone (F14) (the Sangsiah section). The algae in the facies are represented by the species Lithocodium aggregatum (yellow arrow). (O) Miliolid mudstone (F15). (L-O: lagoon). 


\subsubsection{SHOAL SETTING}

The shoal setting (Figure 10) is characterized by a bioclastic, ooidal, and peloidal-grainstone facies (facies F8-F1 1) with a grain-supported texture and abundant non-skeletal grains (ooids and peloids). The presence and distribution of a grain-supported texture, sparite calcite and/or sparitic cement, well-sorted grains, ooids (mainly concentric), and lithic peloids in the grainstone facies indicate high turbulence affecting small-scale bioclastic/ooidal shoals above the fair-weather wave base (Burchette and Wright, 1992; Masse et al., 2003; Palma et al., 2007; Bover-Arnal et al., 2009; Wilmsen et al., 2010; Rahiminejad and Zand-Moghadam, 2018; Aghaei et al., 2019; Raoufian et al., 2019). Also, cross-bedding in the grainstone deposits represents high-energy conditions (Sandulli and Raspini, 2004; Bachmann and Hirsch, 2006; Palma et al., 2007; Wilmsen et al., 2010). Shoal facies is only present in the Sangsiah section (Figure 4).

\subsubsection{LAGOONAL SETTING}

The lagoonal setting (Figure 10) is represented by facies types F12 to F15. Peloids, green algae, and benthic foraminifera (orbitolinids and miliolids) are the most abundant grains in the micritic matrix. The abundance of lime mud and the absence of high-energy textures and sedimentary structures in facies F12 to F15 reflect a low-energy environment (Adachi et al., 2004). The abundance of conical orbitolinids indicates a well-illuminated shallow-water environment (Husinec et al., 2000; Renema and Troelstra, 2001; Pittet et al., 2002; Schroeder et al., 2010; Rahiminejad and Hassani, 2016a, 2016b). The lack of stenohaline organisms and the abundance of euryhaline fauna may point to restricted water circulation in the lagoonal setting (Bosence and Wilson, 2003; Masse et al., 2003; Mancinelli, 2006). However, restricted water circulation in this lagoon is not to be confused with circulation in generally restricted or isolated environments (Read, 1985; Ghabeishavi et al., 2010). The abundance of miliolids and textularids (Vaziri-Moghaddam et al., 2006; Martini et al., 2007; Badenas and Aurell, 2010; Rahiminejad et al., 2018) and green algae (Lithocodium) indicates restricted lagoon conditions (Geel, 2000; Penney and Racey, 2004; Bachmann and Hirsch, 2006; Mansouri-Daneshvar et al., 2015). The lagoon facies was identified in all three studied sections of the Dariyan Formation.

\subsection{GENERAL DEPOSITIONAL MODEL OF THE DARIYAN FORMATION}

The facies types descibed here and their interpretation point to a ramp-type carbonate platform. The lagoon and generally, the shoal settings developed on the inner part of the ramp, whereas the shallow and deep open-marine settings developed on the middle and outer ramp settings (Figure 10).

This general interpretation is in agreement with the lack of genuine slope facies and structures, such as deep-water breccias, reef buildings and faunal frameworks (which can produce rimmed shelves). Moreover, the presence of grain-supported facies in the shoal setting, and the uniform trend of sediment production or accumulation from the shallow open-marine setting towards the deep open-marine setting are all in agreement with a ramp morphology (for interpretation see Read, 1985; Pomar, 2001; Van Buchem et al., 2010; Piryaei et al., 2011; Bai et al., 2017; Aghaei et al., 2019). More specifically, the presence of open-marine, shoal, and lagoonal settings with gradual lateral and vertical changes (Figures 4 to 6 and 10) points to a homoclinal ramp with a gentle slope (Read 1985; Burchette and Wright 1992). Along these lines, the lack of turbidite facies and peri-platform talus (Mcllreath and James, 1984; Payros and Pujalte 2008) in the studied sections supports this concept.

On the other hand, the facies characteristics of the lower unit of the Dariyan Formation in the Seydan and Paskahak sections, and the presence of the deep open-marine setting, reflect deposition in an intra-shelf basin environment (Burchette and Wright, 1992; Cosovic et al., 2004; Flügel, 2010). The limited development of the deep 
open-marine setting indicates that the intra-shelf basin in the Seydan and Paskahak sections was rimmed by shallow carbonate-platform deposits (Ziegler, 2001; Van Buchem et al., 2010).

\subsection{SEQUENGE STRATIGRAPHY}

Change in stacking pattern of strata is a response to the interaction between accommodation and sedimentation rate (Catuneanu et al., 2009, 2011). Sediment accommodation in marine environments is controlled by basin tectonic, subsidence, and sea-level changes on a global scale, whereas sedimentation rate reflects sediment supply (transportation of materials from land and in situ production) and conditions in the basins (Strasser and Samankassou, 2003; Catuneanu et al., 2011). Here, we follow the concepts presented in Catuneanu et al. (2009, 2011). A sequence is defined as sediments between lower and upper boundariesknown as sequence boundaries (SB) - with an abrupt change from a shallowing upward trend to a deepening upward trend. Since in this study the sequence boundaries do not represent any evidence of subaerial exposure, they are regarded as type 2 boundaries. The depositional sequences in the sections of the Dariyan Formation consist of transgressive systems tracts (TSTs) and highstand systems tracts (HSTs), which are characterized by deepening- upward trends and shallowing-upward trends, respectivelly (Figures 4 to 6 and 11). The TSTs and HSTs are separated by maximum flooding surfaces (MSFs) (Figures 4 to 6 and 11). The definition of the orders of sequences is based on the time framework followed by Catuneanu et al. (2009, 2011) and Haq et al. (1988).

Given that the Dariyan Formation in the studied sections is early Aptian to early Albian in age (about 15 My as based on the GTS 2004 time scale; Gradstein et al., 2004; Al-Husseini and Matthews, 2010), a third-order assignment is here proposed for the sequences observed. Hence, we define three third-order depositional sequences (Ds1, Ds2, and Ds3) (Figures 4 to 6 and 11). The conceptual correlations between the depositional sequences of the Dariyan Formation in the studied sections are shown in Figure 11. Depositional sequence 1 and Ds2 comprise TSTs followed by HSTs. In contrast,

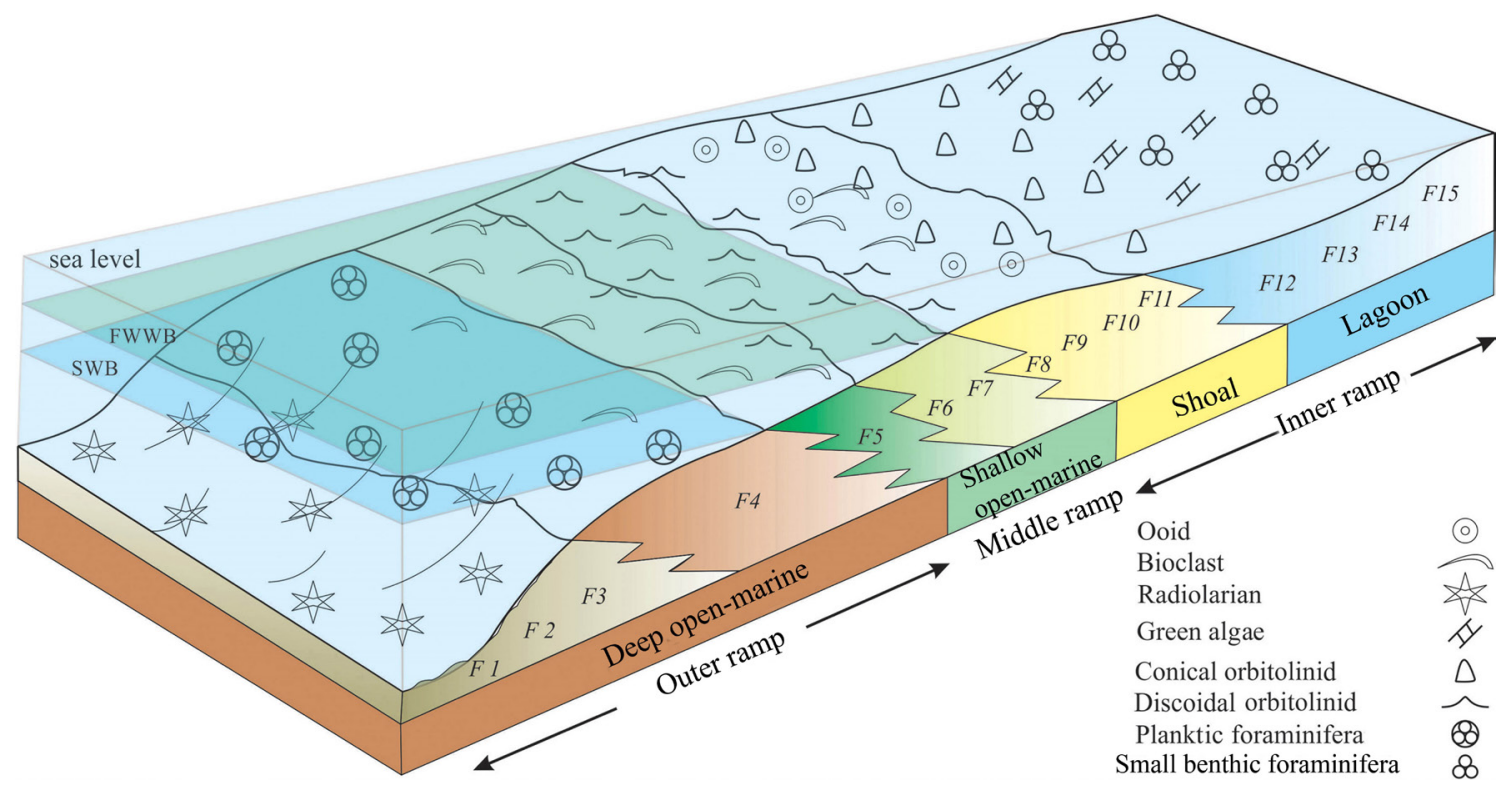

Figure 10 Schematic model proposed for deposition of the Lower Cretaceous deposits in this study. The Dariyan Formation was deposited in deep open-marine, shallow open-marine (o. m.), shoal, and lagoonal settings on a homoclinal ramp. F1: Shale; F2: Marl; F3: Radiolarian wackestone/packstone; F4: Planktic foraminifera wackestone/packstone; F5: Bioclastic wackestone/packstone; F6: Bioclastic rudstone; F7: Discoidal orbitolinid rudstone; F8: Bioclastic grainstone; F9: Ooid grainstone; F10: Peloidal orbitolinid grainstone; F11: Peloidal grainstone; F12: Orbitolinid packstone; F13: Peloidal foraminifera wackestone/packstone; F14: Peloidal green algae wackestone/packstone; F15: Miliolid mudstone. FWWB: fair weather wave base. SWB: storm wave base. 
Ds3 comprises a TST, which its upper boundary is contemporaneous with the boundary between the Dariyan and the Kazhdumi formations (Figures 4 to 6 and 11). The sequence boundaries in all the sequences of the Dariyan Formation belong to the type 2 (SB2) (Figures 4 to 6 and 11). Generally, the Dariyan Formation was deposited on top of the Gadvan Formation during a Aptian sea-level rise (Sharland et al., 2001). The boundary between the Gadvan and the Dariyan formations, which was described as an isochronous boundary in the region (Schroeder et al., 2010), has been regarded as a baseline for the reconstruction of sea-level changes (Van Buchem et al., 2010). The identified depositional sequences in the Dariyan Formation in this study are as follows:

\subsubsection{DEPOSITIONAL SEQUENCE 1 (DS1)}

In the sections of the Dariyan Formation (Figures 4 to 6 and 11), Ds 1 commences with the deposition of carbonates on the upper shale unit of the Gadvan Formation. The lower boundary (SB2-1) of the Ds1, which is the transgressive surface of the Dariyan Formation carbonates, is marked by an abrupt lithological change from shale to limestone and is well recognizable with respect to the erosion of the shale deposits of the upper part of the Gadvan Formation (Figures 4 to 6 and 11).

Additionally, yellow limonitic bioturbations (Figure $7 \mathrm{~K}$ ) were identified at this boundary (in the base of the lower unit of the Dariyan Formation). In the Seydan and Paskahak sections, the deposits in the basal part of the Ds1 are mainly characterized by the packstone and wackestone facies containing bivalves and oyster bioclasts. In the Sangsiah section, the basal part of the Ds1 is marked by the packstone to grainstone facies containing benthic foraminifera such as conical orbitolinids. These facies types are representative of the first transgression resulting from sea-level rise. In the Seydan and Paskahak sections, the upward-decreasing trend of the thicknesses of the beds (towards the upper part of the Dariyan Formation) in the Dariyan Formation and also the presence of the planktic foraminifera and radiolarian-bearing facies are indicative of a TST (in the relevant deposits, nodules and thin grey to black silicified intercalations are observed). At the end of the transgressive trend, the deposition of radiolarian-rich packstone facies (deep, open-marine,) indicates a maximum flooding surface (MFS). In the Seydan and Paskahak sections, this interval is clearly recognizable by intense bioturbations and accumulations of small ammonites ( $3 \mathrm{~cm}$ in size). The first TST in the Paskahak and Seydan sections is 32 $\mathrm{m}$ and $37 \mathrm{~m}$ thick, respectively. Simultaneously, in the Sangsiah section (Figure 4), the change of lagoon packstone facies into shoal grainstone facies and discoidal orbitolinid-rich facies of the shallow open-marine setting, reflects a sea-level rise (TST) recorded in a 40-m thick carbonate succession.

This deepening trend ends with the deposition of the packstone and rudstone facies with discoidal orbitolinids and remains of bivalves and echinoids that indicate the end of the deepening-upward trend and the maximum flooding surface (MFS). In the Sangsiah section, the deposits overlying the MFS boundary mainly contain remains of bivalves and discoidal orbitolinids. In upper portions of the section, poorly-washed facies intercalated with shoal grainstone facies is present. This shallowing-upward trend subsequently leds to ooidal and bioclastic grainstone facies best interpreted as HST. The upper boundary of this facies is equivalent to a second-sequence boundary or the upper boundary of Ds1 (SB2-2). The systems tract is $43 \mathrm{~m}$ thick. Equivalents of such facies in the Seydan (34 m thick) and Paskahak (43 m thick) sections include shales, marls, and planktic foraminifera-bearing argillaceous limestones. These are considered the normal deposits of deep-marine settings and qualify as a HST. At the end of the HST, planktic foraminifera-bearing marls are replaced by argillaceous limestones containing discoidal orbitolinids and fragments of bivalves. The upper surface of the orbitolinid-bearing beds is the upper boundary of the first sequence (SB2-2) in the Seydan and Paskahak sections. At this boundary, deposits with 
scattered small horizontal tunnel-shaped bioturbations (7-10 $\mathrm{mm}$ in diameter) are present. Generally, the presence of benthic foraminifera such as Choffatela decipiens and Palorbitolina lenticularis in the deposits and the appearance of Mesorbitolina parva in the upper boundary of the Ds1 in the studied sections documents that the DS1 in the Dariyan Formation is early Aptian in age (Figures 4 to 6$)$.

\subsubsection{DEPOSITIONAL SEQUENCE 2 (DS2)}

In the Seydan and Paskahak sections (Figures 5 to 6 and 11), the Ds2 is recognized by a change in lithology from shallow open-marine setting argillaceous limestones (with wackestone to packstone facies) to planktic foraminifera-bearing shales of the outer ramp. The lower boundary of the Ds2 correlates and overlaps with the upper boundary of the Ds1 (SB2-2). The planktic foraminifera-bearing marls and shales combined with intercalations of planktic foraminifera-bearing argillaceous limestones form a TST (thicknesses of 16 and $25 \mathrm{~m}$ in the Seydan and Paskahak sections, respectively) in the Ds2. The upper boundary is regarded as a maximum flooding surface.

In the Sangsiah section (Figures 4 and 11), the TST (31 m thick) is defined by the occurrence and distribution of the floatstone to rudstone facies containing discoidal orbitolinids. A deepening

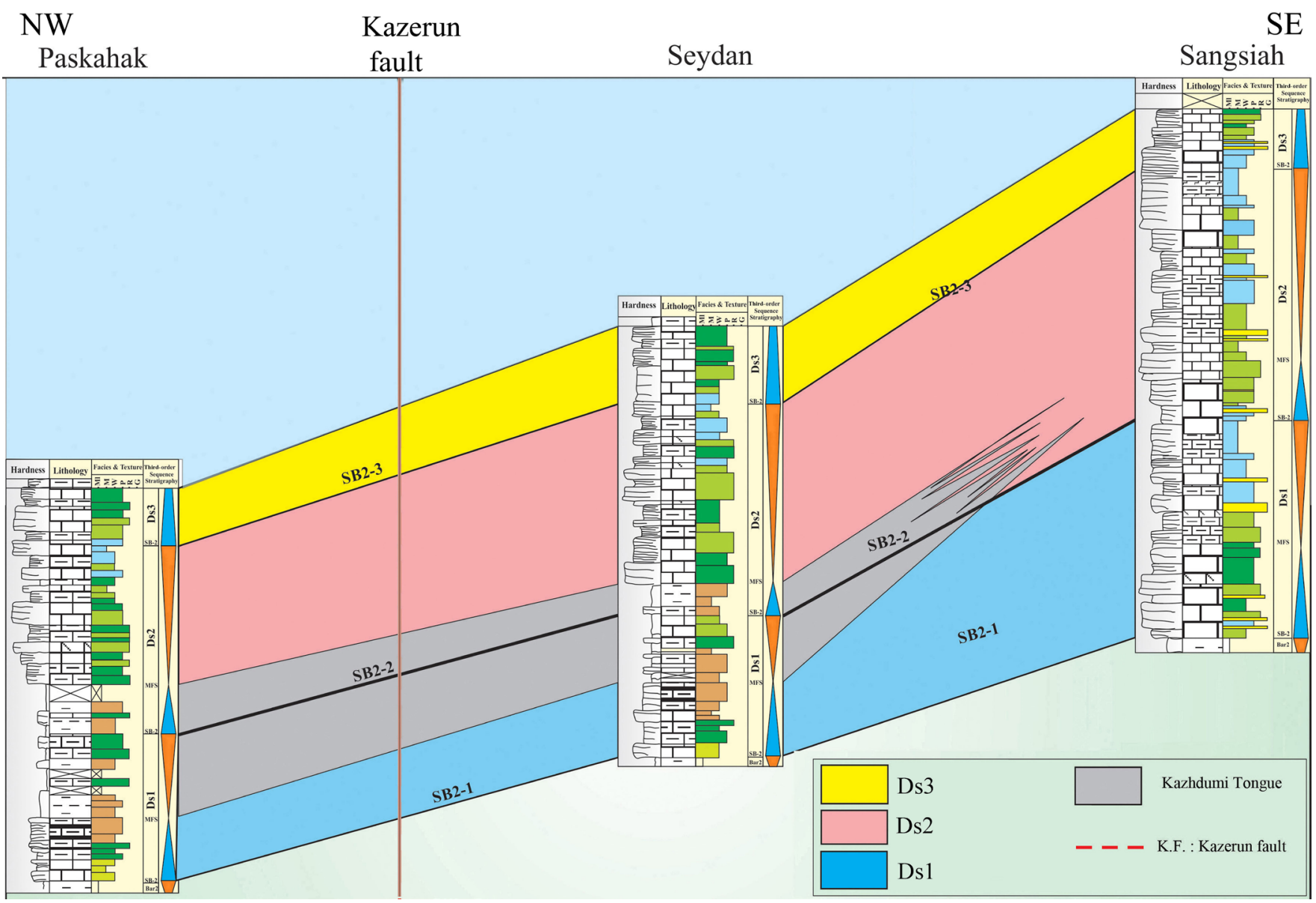

Figure 11 Lithostratigraphic and sequence stratigraphic correlation of the three sections (Paskahak, Seydan, and Sangsiah) of the Dariyan Formation. Biostratigraphic details indicate that the Dariyan Formation in the sections is early Aptian to early Albian in age (see Figures 4 to 6 and 8). The legends for the lithological, facies, and sequence stratigraphical details of the formation in the sections are shown on Figures 4-6. Ds: depositional sequence. SB2: type 2 sequence boundary. 
trend led to development of bioclastic packstone to rudstone facies as the deepest facies in this sequence. The upper surface of the stratigraphic interval with packstone facies (containing bioclasts of echinoid and bivalve) reflects the maximum flooding surface in the Ds2 and is the equivalent to the MFS (the surface above the planktic foraminifera-bearing shales and marls) in the Seydan and Paskahak sections (Figures 5 to 6 and 11).

In the Sangsiah section (Figures 4 and 11), the orbitolinid-rich facies and the shoal facies, such as ooidal and bioclastic grainstones directly overly the MFS. Following the deposition of these facies, a stratigraphically thick interval with lagoonal facies (mainly conical orbitolinid packstonewackestone and packstone with small benthic foraminifera and green algae) was deposited in the Sangsiah section. This facies association, which is representative of a shallowing-upward trend in the Dariyan Formation, is best interpreted as the HST in the Ds2. At the end of the HST, restricted lagoon deposits containing milliolid, pelloids, and green algae were deposited. The upper boundary is interpreted as the upper boundary of the Ds2 (SB2-3). The HST is $80 \mathrm{~m}$ thick.

In the Seydan and Paskahak sections, the deposits, which are equivalent to the HST in the Sangsiah section, overlie the maximum-flooding surface with an abrupt change in lithology. Across this surface or thin interval, packstone facies containing debris of echinoids and bivalves, combined with rudstone facies comprising discoidal orbitolinids, overlie the planktic foraminifera-bearing marls. These facies are followed by a thick succession of lagoon facies mainly including packstone with conical orbitolinids and other benthic foraminifera. The orbitolinids in the facies are reworked and the marginal parts of their tests are commonly eroded. In the Seydan and Paskahak sections, the surface above the stratigraphic interval representing lagoonal facies is the upper boundary of the Ds2 (SB2-3). In the two sections, the thicknesses of the HST are $91 \mathrm{~m}$ and $69 \mathrm{~m}$, respectively.

In the studied sections of the Dariyan Formation, the co-occurrence of Mesorbitolina parva and
Mesorbitolina texana in the lower and middle parts of the Ds2, as well as the presence of Mesorbitolina texana and Mesorbitolina subconcava in the upper parts, document that Ds2 is late Aptian in age (Figures 4 to 6).

\subsubsection{DEPOSITIONAL SEQUENCE 3 (DS3)}

This sequence is the stratigraphically highest and the youngest depositional sequence of the Dariyan Formation in the studied sections (Figures 4 to 6 and 11). This sequence consists of a TST. The occurrence of Mesorbitolina subconcava in the Ds3, as well as the appearance of Hemicyclamina sigali at the end of the Ds3 indicate a latest Aptian to earliest Albian in age (Figures 4 to 6 and 8).

The presence of orbitolinid wackestone facies with discoidal orbitolinids is indicative of a sealevel rise and the deposition of a TST in the Seydan (42 m thick) and Paskahak (31 m thick) sections. The deepening-upward trend of the facies is followed by orbitolinids-rich packstone to rudstone and then by bioclastic packstone towards the upper boundary of the Dariyan Formation. The TST deposits mainly consist of discoidal orbitolinid-bearing limestones. In the boundary between the Dariyan Formation and the overlying Kazhdumi Formation, bioturbation is intense and clearly reflects a decrease in sedimentation rate (omission). Although the omission surface can be considered as a maximum-flooding interval, it is perhaps best interpreted as a flooding surface due to a facies deepening-upward trend from the Dariyan Formation towards the Kazhdumi Formation. This trend is defined by the change in lithology from the orbitolinid-bearing limestones of the Dariyan Formation to the marls (with bivalve shells) and planktic foraminifera-bearing shales of the Kazhdumi Formation. The systems tract, however, represents the first phase of a transgression, which is followed by the second phase in the overlying deposits (e.g., Van Buchem et al., 2010). The maximum flooding interval is present in the Kazhdumi Formation.

In the Sangsiah section (platform top; including shallow open-marine, shoal, and lagoon), the TST 
(42 $\mathrm{m}$ thick) in the Ds3 is marked by a change from wackestone to packstone (containing small, benthic foraminifera (milliolid) and green algae) to conical orbitolinid-bearing limestones and ooid grainstone. This is followed by bivalve-debris-bearing, bioclastic grainstone. The transgressive trend continues by deposition of discoidal, orbitolinid-rich packstone to rudstone and is interrupted by bioclastic rudstone facies containing fragments of bivalves and echinoderms. Based on the abundancy of bioturbations and the deepening-upward trend above the top surface of the Dariyan Formation, this upper boundary might represent a flooding surface. The sea-level rise resulted in conformable deposition of the Kazhdumi Formation on the Dariyan Formation.

\section{Discussion}

Although facies, depositional environments and sequences of the Dariyan Formation have been studied in different areas of the Zagros belt (Table 1), more recent studies (e.g., Mansouri-Daneshvar et al., 2015; Mehrabi et al., 2015; Naderi-Khujin et al., 2016) have been mainly focused, driven by its importance as reservoir unit, on subsurface sections of the Dariyan Formation in the Persian Gulf area (Table 1).

On a larger scale, the sea-level patterns recorded in the Dariyan Formation as reported here are consistent with Early Cretaceous sealevel reconstruction for the Arabian Plate (Figures 4 to 6) (Sharland et al., 2001; Ziegler, 2001; Van Buchem et al., 2010).

Late Barremian to early Aptian sea-level rise resulted in shifting of siliciclastic systems landward and towards their sources and also led to precipitation of siliciclasts in the coastal zones in the west of the basin in the Arabian Plate (Davies et al., 2002). Sea-level rise or transgression in Saudi Arabia is marked by completion of deposition of the Zubair Formation and its equivalent deltaic siliciclastic deposits (Al-Fares et al., 1998) and a change of fluvial deposits of the Biyadh Formation to the marine carbonates of the Shuaiba Formation (Hughes, 2000). Siliciclastic discharge provided favourable conditions for the deposition of the Dariyan Formation and the contemporenous carbonate successions to the east of the Arabian Plate (Sharland et al., 2001; Davies et al., 2002; Van Buchem et al., 2010).

The maximum flooding surface in the Ds1 of the Dariyan Formation in this study is consistent with the upper lower Aptian K80 maximum flooding surface (K80 MFS) of the Arabian Plate (Sharland et al., 2001; Haq and Al-Qahtani, 2005). Deposits associated with K80 MFS have been reported from different parts of the Arabian plate. In the United Arab Emirates, the K80 MFS has been identified in the Bab Tar (source rock) unit of the Shuaiba Formation (Grotsch et al., 1998; Sharland et al., 2001). This surface, which is reflected by a deep facies comprising planktic foraminifera and organic materials, formed during the evolution of the Bab Basin (Grotsch et al., 1998). In Qatar, the K80 MFS is defined by the occurrence of planktic foraminifera-bearing deposits in the upper part of the Shuaiba Formation (Sharland et al., 2001). Also, in the west of Oman the K80 MFS is indicated by the presence of planktic foraminifera mudstone and kerogen-bearing wackestone (Witt and Gökdag, 1994).

In the Seydan and Paskahak sections of the Dariyan Formation, the K80 MFS lies on the pelagic limestones comprising organic materials and oil stains. Generally, the sea-level rise at the end of the early Aptian has been assigned to an eustatic trend (Sharland et al., 2001; Haq and Al-Qahtani, 2005). This transgression or sea-level rise has been associated with the Aptian oceanic anoxic event (OAE 1a) (Leckie et al., 2002; Jenkyns, 2010; Moosavizadeh et al., 2014), resulting from greenhouse conditions, which were related to high input of $\mathrm{CO}_{2}$ into the atmosphere during volcanic activities (Weissert and Erba, 2004; Mehay et al., 2009). Global warming triggered by such conditions could have led to melting of ice sheets (Frakes et al., 2005) and the subsequent global sealevel rise (Skelton and Gili, 2012). In some parts of the Arabian Plate (e.g., the Bab Basin in the United Arab Emirates and the Kazhdumi Basin and the Izeh Zone in Iran), tectonic subsidence enhanced 
Table 1. Comparison of concepts presented here with previous studies. Recent studies have been mainly focused on subsurface sections of the Dariyan Formation in the Persian Gulf Area due to the important reservoir characteristics of this formation.

\begin{tabular}{|c|c|c|c|c|c|}
\hline Formation & Age & Location & Author & $\begin{array}{l}\text { Depositional environments and their } \\
\text { associated facies }\end{array}$ & Sequences \\
\hline Dariyan & $\begin{array}{l}\text { Aptian-early } \\
\text { Albian }\end{array}$ & $\begin{array}{l}\text { 1- Near Shiraz } \\
\text { city, in the Interior } \\
\text { Fars zone. } \\
\text { 2- Near Kazerun } \\
\text { town, in the Izeh } \\
\text { Zone. }\end{array}$ & This study & $\begin{array}{l}\text { Homoclinal ramp } \\
\text { 1- Inner ramp (lagoon): orbitolinid packstone, peloidal- } \\
\text { foraminifera wackestone/packstone, peloidal-green algae } \\
\text { wackestone/packstone, miliolid mudstone } \\
\text { 2- Inner ramp (shoal): bioclastic grainstone, } \\
\text { ooid grainstone, peloidal-orbitolinid grainstone, } \\
\text { peloidal grainstone } \\
\text { 3- Middle ramp (shallow open marine): } \\
\text { bioclastic wackestone/packstone, bioclastic rudstone, } \\
\text { discoidal orbitolinid rudstone } \\
\text { 4- Outer ramp (deep open marine): shale, marl, } \\
\text { radiolarian wackestone/packstone, planktic } \\
\text { foraminifera wackestone/packstone }\end{array}$ & $\begin{array}{l}\text { 1-Three third-order depositional } \\
\text { sequences (Ds1, Ds2 and Ds3). } \\
\text { First sequence (Ds1): lower Aptian. } \\
\text { Second and third sequences (Ds2 and } \\
\text { Ds3): upper Aptian-lower Albian. } \\
\text { 2-Three type } 2 \text { sequence boundaries } \\
\text { (SB2). }\end{array}$ \\
\hline Dariyan & Aptian & South of Semirom & $\begin{array}{l}\text { Hamedanian et } \\
\text { al., } 2016\end{array}$ & $\begin{array}{l}\text { Homoclinal carbonate platform } \\
\text { 1- Open marine: pelagic mudstone, bioclastic wackstone } \\
\text { 2- Barrier: peloidal grainstone, Orbitolina-bioclastic } \\
\text { grainstone, Orbitolina-bioclastic wackestone/packstone, } \\
\text { bioclastic-bivalvida packstone/floatstone, bioclastic- } \\
\text { algae-rudstone } \\
\text { 3-Lagoon: bioclastic-Orbitolina wackestone/packstone, } \\
\text { bioclastic-algae wackestone/packstone }\end{array}$ & $\begin{array}{l}\text { 1-Three depositional sequences (Sq1, } \\
\text { Sq2 and Sq3). } \\
\text { The first sequence (Sq1) comprises } \\
\text { the upper Barremian-lower Aptian } \\
\text { deposits of the Gadvan Formation and } \\
\text { the lower Aptian deposits of the } \\
\text { Dariyan Formation. } \\
\text { Sq2: lower Aptian-upper Aptian. } \\
\text { Sq3: upper Aptian. } \\
\text { 2-Two type } 1 \text { (SB1) and two type } 2 \\
\text { (SB2) sequence boundaries. }\end{array}$ \\
\hline Dariyan & $\begin{array}{l}\text { Barremian- } \\
\text { early Aptian }\end{array}$ & $\begin{array}{c}\text { Central Persian } \\
\text { Gulf }\end{array}$ & $\begin{array}{l}\text { Naderi-Khujin et } \\
\quad \text { al., } 2016\end{array}$ & $\begin{array}{l}\qquad \text { Ramp } \\
\text { 1- Peritidal: laminated mudstone, dolomitic mudstone } \\
\text { 2- Lagoon: Lithocodium-Bacinella floatstone } \\
\text { 3- Lagoon-restricted open marine: bioclastic wackestone } \\
\text { 4- Leeward shoal-shoal: peloidal-bioclastic packstone, } \\
\text { intraclastic-peloidal bioclastic packstone/grainstone } \\
\text { 5- Open marine: fossiliferous mudstone (rare planktic } \\
\text { foraminifera, radiolarian fragments) }\end{array}$ & 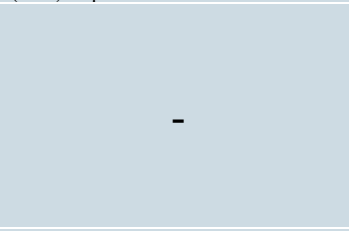 \\
\hline Dariyan & Aptian & $\begin{array}{l}\text { Western Persian } \\
\text { Gulf }\end{array}$ & $\begin{array}{c}\text { Mehrabi et al., } \\
2015\end{array}$ & $\begin{array}{l}\text { Carbonate ramp to deep intra-shelf basin and delta } \\
\text { 1- Inner ramp (lagoon): benthic foraminifera-green algal } \\
\text { wackestone/packstone } \\
2 \text { - Inner ramp (lagoon): peloidal coated-grain } \\
\text { wackestone } \\
3 \text { - Inner ramp (patch reef mound): Lithocodium-algal } \\
\text { floatstone/boundstone } \\
4 \text { - Inner-middle ramp (shoal): bioclastic-peloidal } \\
\text { packstone/grainstone } \\
5 \text { - Middle ramp (proximal): Orbitolina-bioclastic } \\
\text { wackestone/packstone } \\
6 \text { - Middle ramp (distal): echinoderm-sponge spicule } \\
\text { wackestone } \\
7-\quad \text { Outer ramp: Micro-peloid-microbioclastic } \\
\text { mudstone/wackestone } \\
8-\text { Intra-shelf basin: pelagic mudstone/marl (containing } \\
\text { planktic foraminifera) } \\
9 \text { - Proximal delta: sandy ooidal ironstone } \\
10-\text { Proximal delta: wavy bedded and bioturbated } \\
\text { sandstone/siltstone } \\
11-\text { Prodelta (distal delta): shale/silty shale/marl } \\
\text { (containing planktic foraminifera) }\end{array}$ & $\begin{array}{l}\text { 1- Two super sequences and four } \\
\text { third-order sequences. } \\
\text { 2- Second and third order depositional } \\
\text { sequences. }\end{array}$ \\
\hline Dariyan & Aptian & $\begin{array}{l}\text { Eastern Persian } \\
\text { Gulf, } \\
\text { Qeshm Island and } \\
\text { offshore }\end{array}$ & $\begin{array}{l}\text { Mansouri- } \\
\text { Daneshvar } \text { et al., } \\
2015\end{array}$ & $\begin{array}{l}\text { Carbonate ramp system to intrashelf basin } \\
\text { 1- Inner ramp (tidal flat): Sandy mudstone } \\
\text { 2- Inner ramp (restricted lagoon and bar): milliolidae } \\
\text { wackestone/pellet grainstone, } \\
\text { 3- Inner ramp (restricted lagoon and bar): benthic } \\
\text { foraminifera wackestone/pellet grainstone } \\
\text { 4- Inner ramp (restricted to open lagoon): conical } \\
\text { Orbitolina wackestone/packstone } \\
\text { 5- Middle ramp: rudist rudstone, coral rudstone, } \\
\text { Lithocodium aggregatum rudstone/oundstone, echinoid } \\
\text { pellet grainstone, discoidal Orbitolina } \\
\text { wackestone/packstone, bioclastic wackestone/packstone } \\
\text { 6- Outer ramp: Lenticulina-Epistomina wackestone } \\
\text { 7- Outer ramp-intra shelf: sponge spicule } \\
\text { wackestone/packstone } \\
\text { 8- Intra-shelf: pyritized mudstone (contains radiolarian } \\
\text { and orbitolinids), pelagic foraminifera wackestone }\end{array}$ & $\begin{array}{l}\text { 1- Five third-order depositional } \\
\text { sequences. } \\
\text { 2- Three type } 1 \text { (SB1) and three type } \\
2 \text { (SB2) sequence boundaries. }\end{array}$ \\
\hline
\end{tabular}


the relative sea-level rise (Sharland et al., 2001; Ziegler, 2001; Van Buchem et al., 2010). The deposition of the Dariyan Formation in the Paskahak section in the Izeh Zone was controlled by tectonic subsidence. According to Van Buchem et al. (2002, 2010) and other workers, a sudden facies deepening-upward trend is the main evidence of the role of tectonic subsidence in increasing sea-level rise in such basins (Sharland et al., 2001; Ziegler, 2001).

The activities of the Kazerun and Hendijan strike-slip faults are considered the main parameters controlling the basin subsidence in the Kazhdumi Basin during the early Aptian (Sharland et al., 2001; Ziegler, 2001; Van Buchem et al., 2010). The Kazerun fault system with a north-trending dextral strike-slip fault is one of the basement structures that probably originated from the Pan-African basement from a Neoproterozoic tectonic phase and divides the Zagros into two separate along-strike blocks (Talbot and Alavi, 1996; Nankali, 2011). The fault activity controlled the sedimentation pattern and structural deformation of the Phanerozoic deposits and remains seismically active to the Present day (Tavakoli et al., 2008). Based on the isopach and facies maps of the Zagros belt (Setudehnia, 1978; Koop and Stoneley, 1982), the activity of the Kazerun and Izeh faults controlled the sedimentation patterns of this belt in the Early Cretaceous (Sepehr and Cosgrove, 2004, Nankali, 2011). Van Buchem et al. (2010) documented that the vertical movements of the Kazerun and Hendijan faults resulted in a subsidence with a thickness of about $170 \mathrm{~m}$ during the late early Aptian to the early Albian in the basin.

A similar facies change has been also reported from the Cenomanian-Turonian (Sarvak Formation) and the Campanian-Eocene (Gurpi and Pabdeh formations) deposits (Sepehr and Cosgrove, 2004). Facies changes resulted from the activity of the Kazerun fault, which formed an area with rapid subsidence in the east and a more stable area in the west of the fault zone (Sepehr and Cosgrove, 2004). Additionally, during the Miocene, the Kazerun fault acted as a boundary that controlled the extension of the salt basin of the Gachsaran Formation (Sepehr and Cosgrove, 2004; Safaei, 2009). The subsidence resulted in formation of a depocenter, which is entirely surrounded by a shallow carbonate platform (James and Wynd, 1965; Sharland et al., 2001; Ziegler, 2001).

In this study, the abrupt deepening-upward trend in the Dariyan Formation (in the Paskahak and Seydan sections) was recorded in the TST in Ds1, where shallow-marine limestones switch to deep-marine argillaceous limestones rich in planktic foraminifera and radiolarians. Given that the equivalent deposits in the Sangsiah section display only a normal deepening-upward trend, and that the deep-water deposits of the Kazhdumi Tongue pinch out from the Seydan towards the Sangsiah sections (Figure 11), the abrupt facies change suggests that the relative sea-level rise was caused by tectonic subsidence (e.g., Ziegler, 2001; Van Buchem et al., 2010) (Figure 12). The tectonic subsidence in the Paskahak section in the Izeh Zone has been attributed to the Kazerun fault activity (Sharland et al., 2001; Ziegler, 2001; Van Buchem et al., 2010).

With respect to the geological features of the Seydan section and its surrounding area, three factors likely contributed to enhancing the subsidence in the eastern part of the Kazerun fault:

1. The activity of another basement fault, the Bahar (Kareh-Bas) fault (e.g., Tavakoli et al., 2008) (Figure 13A). The tectonic features of this strike-slip fault are similar to those of the Kazerun fault. The two faults are parallel (Tavakoli et al., 2008; Nissen et al., 2011). The Bahar fault could have been active during the development of deep-marine settings, contemporaneous with the Kazerun fault.

2. The middle Cretaceous extensional fault systems that have been reported by Navabpour et al. (2010) in the east of the Kazerun fault (Figure 13B). The activation of these fault systems which were synchronous with subduction of the Neo-Tethys oceanic crust toward the north, could have contributed to the subsidence in the eastern part of the Kazerun fault. 
3. The third factor is related to salt movement. The deposition of deep-water deposits in the Seydan section was contemporaneous with the formation and development of the Bab Basin (with deep-water planktic foraminifera and radiolarian-rich deposits) between Oman and the United Arab Emirates. In the Bab Basin, pelagic deposits of the Nahr Umr Formation are deposited and surrounded by carbonate-platform deposits of the Kharaib and Shuaiba formations (Sharland et al., 2001;
Ziegler, 2001). In the basin, movement of the infra-Cambrian Hormuz Salt has been suggested as the main factor controlling the subsidence and formation of the Bab Basin (Sharland et al., 2001; Al-Ghamdi, 2006). With respect to the extension of the Hormuz salt basin in east and southeast of the Kazerun fault (the Shiraz Basin; Figure 13G) (Motiei, 1993), subsidence progressed towards the inner areas of the Interior Fars (east of the Kazerun fault). This feature was probably

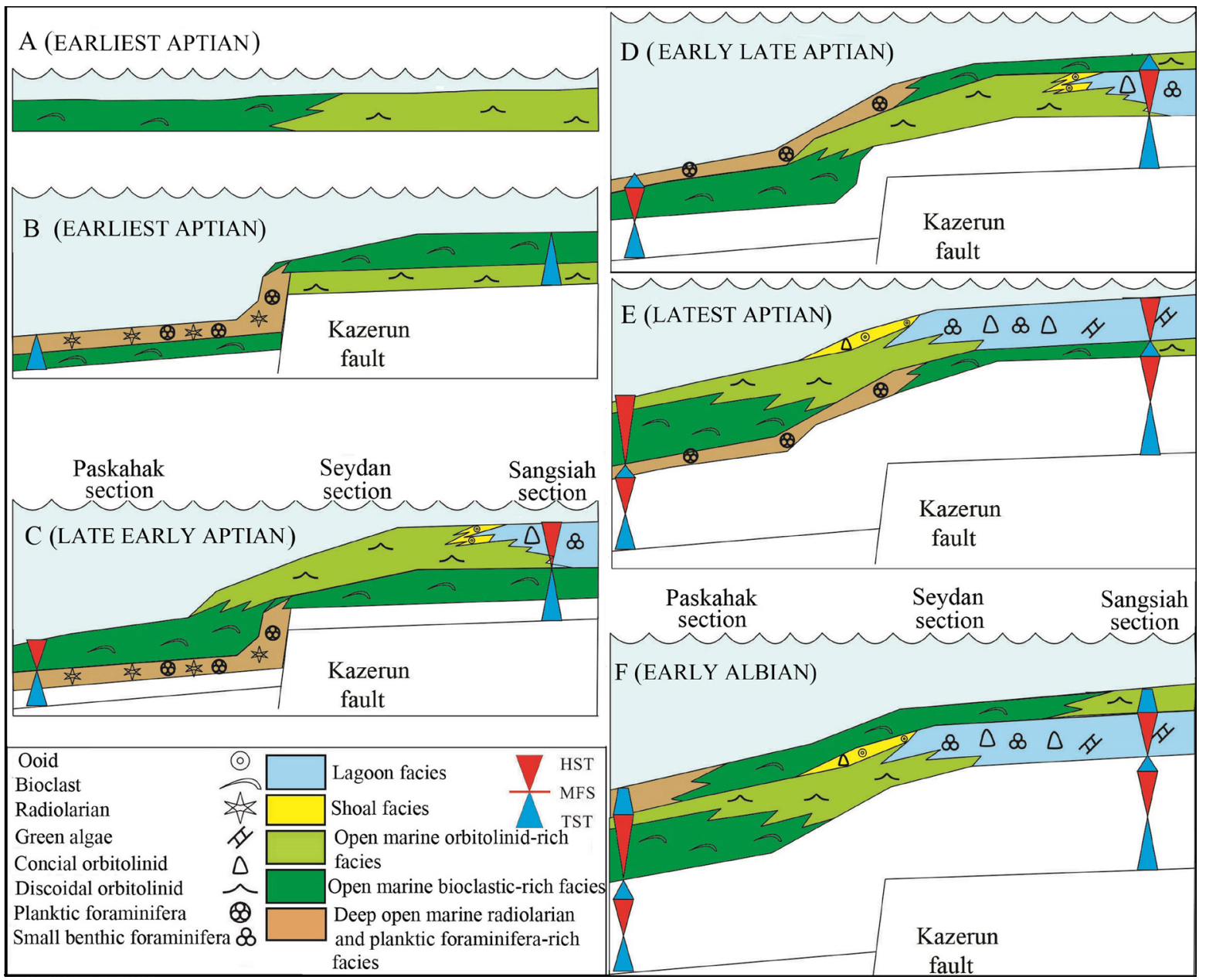

Figure 12 Schematic models of the sequence evolution representing the relative influence of sea-level changes and tectonic subsidence in the studied sections (not to scale). (A) Initial sea-level transgression or sea-level rise and initial deposition of the Dariyan Formation on the Barremian Gadvan Formation (earliest Aptian). (B) Deposition of radiolarian-bearing facies of the Dariyan Formation during deep open-marine subsidence and sea-level rise (earliest Aptian). (C) Highstand systems tracts led to deposition of orbitolinid-rich facies in the deep open-marine setting (outer ramp) (late early Aptian). (D) Sea-level rise led to deposition of planktic foraminifera-bearing deposits (early late Aptian). (E) Sea-level fall and progradation of platform top (shallow open-marine, shoal, and lagoonal settings) deposits into the outer ramp (deep open-marine setting) (latest Aptian). (F) Deposition of the Albian Kazhdumi Formation on the AptianAlbian Dariyan Formation during the sea-level rise (early Albian). 
related to movement of the infra-Cambrian Hormuz Salt. Tectonic forces that resulted in the activity of the Kazerun and Bahar faults and/or the extensional fault systems triggered the salt movement (e.g., Sharland et al., 2001; Piryaei et al., 2011). The flow of salt diapirs and development of salt domes related to fault activity, is a feature that has been documented in the literature (e.g., Tavakoli et al., 2008; Navabpour et al., 2010; Nissen et al., 2011).

In the upper Aptian interval of the Seydan and Paskahak sections, a transgression which was mainly controlled by eustatic sea-level change was associated with the progradation of shallow orbitolinid-rich carbonate-platform facies over the shale and marl pelagic deposits of the top surface of the Kazhdumi Tongue. These pronounced lithological and facies changes witness the progradation of platform top deposits into the deepest part of the basin due to the rapid sea-level fall (i.e., forced regression; e.g., Sharland et al., 2001; Van Buchem et al., 2010). Moreover, the presence of grain-supported facies with eroded grains (such as orbitolinids) supports these interpretations. Based on the age of the upper unit of the Dariyan Formation (late Aptian) (Schroeder et al., 2010), deposition of the Ds2 co-occurred with a phase of global sea-level fall and subaerial exposure of a wide area of the Arabian Platform. Thus, on
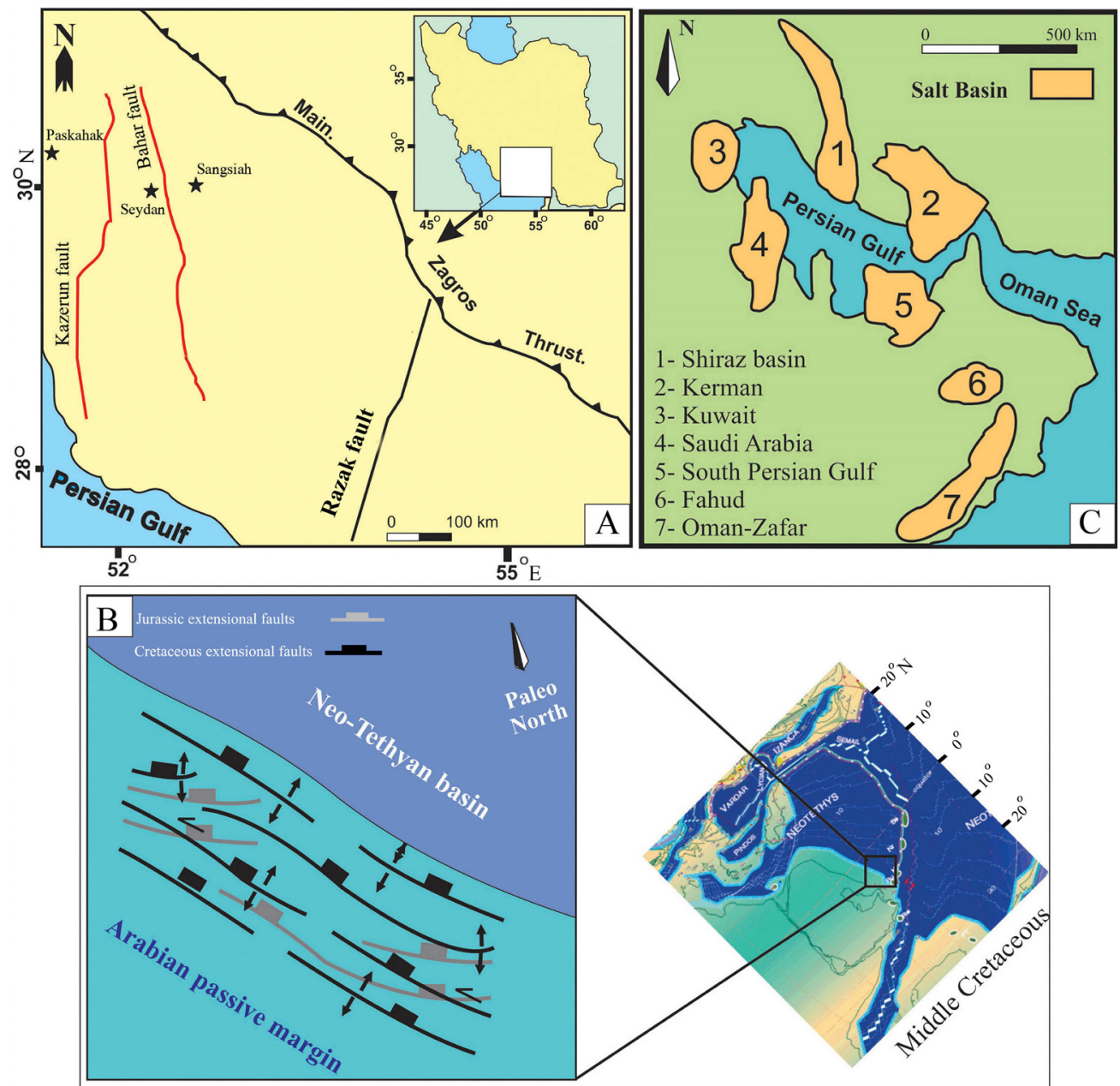

Figure 13 (A) Dispersion pattern of the strike-slip basement faults in the Zagros belt. The studied sections are marked by black stars (Simplified from Tavakoli et al., 2008). (B) Extensional fault systems in the northeastern part of the Arabian Plate during the Aptian (Navabpour, 2010). (C) Salt basin dispersion around the Persian Gulf. (Simplified from Motiei, 1993). 
a regional scale, the carbonate deposits of the upper unit of the Dariyan Formation is a lowstand systems tract (LST) on the Arabian Platform (Sharland et al., 2001; Ziegler, 2001; Schroeder et al., 2010; Van Buchem et al., 2010; Maurer et al., 2013).

The subaerial exposures of the Arabian Platform, and the disconformity surface on the top of the Shuaiba and Qishn formations, have been reported from for example Oman (Rameil et al., 2012). Also, the subaerial exposure of the carbonate platform of the Dariyan Formation after the late early Aptian has been recorded as karstification in carbonate deposits and palaeosols in several sections such as Kuh-e-Gach and Kuh-e-Asaluyeh in north of the Persian Gulf region (coastal Fars province) (Van Buchem et al., 2010).

The subaerial exposure (of the platform top) and hiatal intervals in these sections resulted in development of a diachronous surface in the upper boundary of the Dariyan Formation (Schroeder et al., 2010; Van Buchem et al., 2010).

Moreover, late Aptian lowstand systems tract deposits have also been reported from other regions. Examples include the Russian platform where a pronounced sea-level fall resulted in an extensive erosion of the platform top deposits (Sahagian et al., 1996). Similarly extensive erosional events as well as deposits in incised valleys have also been recorded in the west of Siberia (Medvedev et al., 2011). Simultaneously, extensive subaerial exposures developed on the carbonate platforms in Portugal (Heimhofer et al., 2007) and Spain (Rodríguez-López et al., 2008). All of these features show that the carbonate platforms in the western margin of the Neotethys Ocean were subaerially exposed during the late Aptian (Maurer et al., 2013).

Detailed stratigraphic-sequence studies and oxygen isotope analyses revealed that during the late Aptian, periods of global cooling, contemporaneous with sea-level fall and subaerial exposures of platforms, prevailed (Maurer et al., 2013). Ice sheet dynamics and development and growth of ice caps have been considered as the most probable factors resulting in eustatic sea-level fall (Maurer et al., 2013). Transgression or sea-level rise in the Albian led to deposition of the Kazhdumi Formation on the carbonate deposits of the Dariyan Formation (Sharland et al., 2001; Ziegler, 2001). The relative effects of tectonic subsidence and relative sea-level changes in the studied sections of the Dariyan Formation are shown in Figure 12.

\section{Conclusions}

The Lower Cretaceous Dariyan Formation was studied in three stratigraphic sections in the Interior Fars (the Sangsiah and Seydan sections) and the Izeh Zone (the Paskahak section) of the Zagros fold-thrust belt in the south-west of Iran. Based on the palaeontological studies, the following age assigning benthic foraminifera were identified in the Dariyan Formation: Choffatella decipiens, Archaealveolina sp., Palorbitolina lenticularis, Mesorbitolina parva, Mesorbitolina texana, Mesorbitolina subconcava, and Hemicyclammina sigali. The stratigraphic range of these foraminifera supports the notion that that the Dariyan Formation is early Aptianearly Albian in age.Detailed sedimentological and stratigraphic studies documented that the Dariyan Formation was deposited in deep open-marine, shallow open-marine, shoal, and lagoon depositional settings in the outer, middle, and inner parts of a homoclinal ramp.

Three type 2 sequence boundaries (SB2,) and three third-order depositional sequences (Ds1, Ds2 and Ds3) are here defined. The depositional sequences consist of three transgressive systems tracts (TSTs) and two highstand systems tracts (HSTs), respectively.

The following stages explain the deposition of the Aptian-Albain Dariyan Formation in the studied area:

1. Earliest Aptian: sea-level rise and initial deposition of the Dariyan Formation sediments on the Barremian Gadvan Formation.

2. Earliest Aptian: deposition of the radiolarian-bearing facies of the Dariyan Formation during deep open-marine subsidence and sea-level rise. 
3. Late early Aptian: deposition of orbitolinid-rich facies in the deep open-marine setting

4. due to the formation of highstand systems tracts (HSTs).

5. Early late Aptian: deposition of planktic foraminifera-bearing facies during the subsequent sea-level rise.

6. Latest Aptian: progradation of the platform top (shallow open-marine, shoal, and lagoon) deposits of the Dariyan Formation into the deep open-marine setting due to the sea-level fall.

7. Early Albian: deposition of the Albian Kazhdumi Formation on the Aptian-Albian Dariyan Formation during the subsequent sea-level rise.

Generally, the development of the deep open-marine facies in the Dariyan Formation was related to the subsidence controlled by fault activities during the Aptian.

Work show here suggests that the sea-level patterns recorded for the Dariyan Formation are consistent with the record of relative and eustatic sea level described throughout the Arabian Plate.

\section{Acknowledgements}

A part of this research (study of the Paskahak section) was financially supported by Shahid Bahonar University of Kerman. The authors gratefully acknowledge the Editor-in-Chief (Dr. Antoni Camprubí) and the reviewers for their helpful suggestions and comments that improved the manuscript. The authors gratefully appreciate Prof. Adrian Immenhauser (Ruhr-Universität Bochum, Bochum, Germany) for his very valuable contribution to improving the English edition of the manuscript.

\section{References}

Adachi, N., Ezaki, Y., Liu, J., 2004, The fabrics and origins of peloids immediately after the end-Permian extinction, Guizhou Province,
South China: Sedimentary Geology, 164(12), 161-178. https://doi.org/10.1016/j. sedgeo.2003.10.007

Aghaei, A., Zand-Moghadam, H., MoussaviHarami, R., Mahboubi, A., 2019, Sequence stratigraphic analysis and sea-level history of the Upper Jurassic deposits (Mozduran Formation), south of Aghdarband, NE Iran: Historical Biology, 31(8), 1097-1114. https:// doi.org/10.1080/08912963.2017.1421184

Alavi, M., 2004, Regional stratigraphy of the Zagros fold-thrust belt of Iran and its proforeland evolution: American Journal of Science, 304(1), 1-20. https://doi. org/10.2475/ajs.304.1.1

Alavi, M., 2007, Structures of the Zagros foldthrust belt in Iran: American Journal of Science, 307(9), 1064-1095. https://doi. org/10.2475/09.2007.02

Al-Fares, A.A., Bouman, M., Jeans, P., 1998, A new look at the Lower to Middle Cretaceous stratigraphy, offshore Kuwait: GeoArabia, 3(4), 543-560.

Al-Ghamdi, N.M., 2006, Facies, Sequence Framework, and Evolution of Rudist Buildsup, Shu'aiba Formation, Saudi Arabia: Virginia, U.S.A., the Virginia Polytechnic Institute and State University, MSc thesis.

Al-Husseini, M.I., Matthews, R.K., 2010, Tuning Late Barremian-Aptian Arabian Plate and global sequences with orbital periods, in Van Buchem, F.S.P., Al-Husseini, M.I., Maurer, F., Droste, H.J. (eds.), Barremian-Aptian stratigraphy and hydrocarbon habitat of the eastern Arabian Plate: Manama, Bahrain, GeoArabia Special Publication 4, 199-228.

Bachmann, M., Hirsch, F., 2006, Lower Cretaceous carbonate platform of the eastern Levant (Galilee and the Golan Heights): stratigraphy and second-order sea-level change: Cretaceous Research, 27(4), 487-512. https://doi.org/10.1016/j. cretres.2005.09.003

Badenas, B., Aurell, M., 2010, Facies models of a shallow-water carbonate ramp based on distribution of non-skeletal 
grains (Kimmeridgian, Spain): Facies, 56(1), 89-110. https://doi.org/10.1007/ s 10347-009-0199-z

Bai, H.Q., Betzler, C., Erbacher, J., Reolid, J., Zuo, F., 2017, Sequence stratigraphy of Upper Jurassic deposits in the North German Basin (Lower Saxony, Süntel Mountains): Facies, 63(3), 19. https://doi.org/10.1007/ s10347-017-0501-4

Bassi, D., Nebelsick, J.H., 2010, Components, facies and ramps: redefining Upper Oligocene shallow water carbonates using coralline red algae and larger foraminifera (Venetian area, northeast Italy): Palaeogeography, Palaeoclimatology, Palaeoecology, 295(12), 258-280. https://doi.org/10.1016/j. palaeo.2010.06.003

Berberian, M., King, G., 1981, Towards a paleogeography and tectonic evolution of Iran: Canadian Journal of Earth Sciences, 18(2), 210-265. https://doi.org/10.1139/e81-019

Beydoun, Z.R., Clarke, M.W.H., Stoneley, R., 1992, Petroleum in the Zagros Basin: a late Tertiary foreland basin overprinted onto the outer edge of a vast hydrocarbonrich Paleozoic-Mesozoic passive-margin shelf, in Macqueen, R.W., Leckie, D.A. (eds.), Foreland Basins and Fold Belts, No. 55: American Association of Petroleum Geologists Memoir, 309-339.

Bosence, D.W.J., Wilson, R.C.L., 2003, Carbonate depositional systems, in Coe, A.L. (ed.), The Sedimentary Record of Sea-Level Change: Milton Keynes, UK, Cambridge University Press, 209-233.

Boudagher-Fadel, M.K., 2008, Evolution and geological significance of larger benthic foraminifera: Amsterdam, Netherlands, Elsevier, 571 p. https://doi.org/10.1016/ s0920-5446(08)00012-5

Bover-Arnal, T., Salas, R., Moreno-Bedmar, J.A., Bitzer, K., 2009, Sequence stratigraphy and architecture of a late Early-Middle Aptian carbonate platform succession from the western Maestrat Basin (Iberian
Chain, Spain): Sedimentary Geology, 219(14), 280-301. https://doi.org/10.1016/j. sedgeo.2009.05.016

Burchette, T., Wright, V., 1992, Carbonate ramp depositional systems: Sedimentary Geology, 79(1-4), 3-57. https://doi. org/10.1016/0037-0738(92)90003-a

Catuneanu, O., Abreu, V., Bhattacharya, J.P., Blum, M.D., Dalrymple, R.W., Eriksson, P.G., Fielding, C.R., Fisher, W.L., Galloway, W.E., Gibling, M.R., Giles, K.A., Holbrook, J.M., Jordan, R., Kendall, G.G.St.G., Macurda, B., Martinsen, O.J., Miall, A.D., Neal, J.E., Nummedal, D., Pomar, L., Posamentier, H.W., Pratt, B.R., Sarg, J.F., Shanley, K.W., Steel, R.J., Strasser, A., Tucker, M.E., Winker, C., 2009, Towards the standardization of sequence stratigraphy: Earth-Science Reviews, 92(1-2), 1-33. https://doi. org/10.1016/j.earscirev.2008.10.003

Catuneanu,O.,Galloway,W.E., Kendall,G.G.St.C., Miall, A.D., Posamentier, H.W., Strasser, A., Tucker, M.A., 2011, Sequence stratigraphy: Methodology and nomenclature: Newsletters on Stratigraphy, 44(3), 173-245. https://doi. org/10.1127/0078-0421/2011/0011

Corda, L., Brandano, M., 2003, Aphotic zone carbonate production on a Miocene ramp, Central Apennines, Italy: Sedimentary Geology, 161(1-2), 55-70. https://doi. org/10.1016/s0037-0738(02)00395-0

Cosovic, V., Drobne, K., Moro, A., 2004, Paleoenvironmental model for Eocene foraminiferal limestones of the Adriatic carbonate platform (Istrian Peninsula): Facies, 50(1), 61-75. https://doi.org/10.1007/ s10347-004-0006-9

Davies, R.B., Casey, D.M., Horbury, A.D., Sharland, P.R., Simmons, M.D., 2002, Early to mid-Cretaceous mixed carbonatesiliciclastic shelfal systems: examples, issues and models from the Arabian plate: GeoArabia, 7, 541-598.

Dickson, J.A.D., 1966, Carbonate identification and genesis as revealed by staining: Journal 
of Sedimentary Research, 36, 441-505. https://doi.org/10.1306/74d714f6-2b21 $11 \mathrm{~d} 7-8648000102 \mathrm{c} 1865 \mathrm{~d}$

Dunham, R.J., 1962, Classification of carbonate rocks according to depositional texture, in Ham, W.E. (ed.), Classification of carbonate rocks: Tulsa, Oklahoma, U.S.A., American Association of Petroleum Geologists Memoir, 108-121.

Embry, A.F., Klovan, J.E., 197 1, A late Devonian reef tract on northeastern Banks Island, NWT: Bulletin of Canadian Petroleum Geology, 19, 730-781.

Fakhari, M.D., Axen, G.J., Horton, B.K., Hassanzadeh, J., Amini, A., 2008, Revised age of proximal deposits in the Zagros foreland basin and implications for Cenozoic evolution of the High Zagros: Tectonophysics, 451(1-4), 170-185. https:// doi.org/10.1016/j.tecto.2007.11.064

Flügel, E., 2010, Microfacies of Carbonate Rocks: Analysis, Interpretation and Application: Berlin, Heidelberg, New York, Springer-Verlag, 984 p. https://doi. org/10.1007/978-3-662-08726-8

Frakes, L.A., Francis, J.E., Syktus, J.I., 2005, Climate modes of the Phanerozoic: Cambridge, Cambridge University Press, 288 p. https:// doi.org/10.1017/CBO9780511628948

Geel, T., 2000, Recognition of stratigraphic sequences in carbonate platform and slope deposits: empirical models based on microfacies analysis of Paleogene deposits in southeastern Spain: Palaeogeography, Palaeoclimatology, Palaeoecology, 155(34), 211-238. https://doi.org/10.1016/ s0031-0182(99)00117-0

Ghabeishavi, A., Vaziri-Moghaddam, H., Taheri, A., Taati, F., 2010, Microfacies and depositional environment of the Cenomanian of the Bangestan Anticline, SW Iran: Journal of Asian Earth Sciences, 37(3), 275-285. https://doi. org/10.1016/j.jseaes.2009.08.014

Grabau, A.W., 1904, On the classification of sedimentary rocks: American Geologist, 33, 228-247.
Gradstein, F.M., Ogg, J.G., Smith, A.G., 2004, A Geologic Time Scale 2004: Cambridge, UK, Cambridge University Press, 589 p.

Grotsch, J., Billing, I., Vahrenkamp, V., 1998, Carbon-isotope stratigraphy in shallow-water carbonates: Implications for Cretaceous black-shale deposition: Sedimentology, 45(4), 623-634. https://doi. org/10.1046/j.1365-3091.1998.00158.x

Habibi, T., 2016, Bio- and sequence stratigraphy and microfacies analysis of the Oligocene Asmari Formation at Sepidar Anticline, Interior Fars sub-Basin, SW Iran: Historical Biology, 28(4), 519-532. https://doi.org/10. 1080/08912963.2014.990388

Hamedanian, M.K., Vaziri, S.H., Amir Shakarami, M., Arian, M., Arzani, N., 2016, Microfacies, Sedimentary Environment and Sequence Stratigraphy of Gadvan and Darian Formations in the Zagros Basin, South of Semirom: Open Journal of Geology, 6, 1169-1186. http://dx.doi.org/10.4236/ ojg.2016.69086

Haq, B.U., Al-Qahtani, A.B., 2005, Phanerozoic cycles of sea-level change on the Arabian Platform: GeoArabia, 10, 127-160.

Haq, B.U., Hardenbol, J., Vail, P.R., 1988, Mesozoic and Cenozoic chronostratigraphy and cycles of sea-level change: Society of Economic Paleontologists and Mineralogists Special Publication, 42, 71-108. https://doi. org/10.2110/pec.88.01.0071

Heimhofer, U., Hochuli, P.A., Burla, S., Weissert, H., 2007, New records of Early Cretaceous angiosperm pollen from Portuguese coastal deposits: implications for the timing of the early angiosperm radiation: Review of Palaeobotany and Palynology, 144(12), 39-76. https://doi.org/10.1016/j. revpalbo.2005.09.006

Heydari, E., 2008, Tectonics versus eustatic control on supersequences of the Zagros Mountains of Iran: Tectonophysics, 451(1-4), 56-70. https://doi.org/10.1016/j.tecto.2007.11.046 
Huck, S., Rameil, N., Korbar, T., Heimhofer, U., Wieczorek, T.D., Immenhauser, A., 2010, Latitudinally different responses of Tethyan shoal-water carbonate systems to the Early Aptian oceanic anoxic event (OAE 1a): Sedimentology, 57(7), 1585-1614. https:// doi.org/10.1111/j.1365-3091.2010.01157.x

Huck, S., Heimhofer, U., Rameil, N., Bodin, S., Immenhauser, A., 2011, Strontium and carbon-isotope chronostratigraphy of Barremian-Aptian shoal-water carbonates: Northern Tethyan platform drowning predates OAE 1a: Earth and Planetary Science Letters, 304(3-4), 547-558. https:// doi.org/10.1016/j.epsl.2011.02.031

Hughes, G., 2000, Saudi Arabian Late Jurassic and Early Cretaceous agglutinated foraminiferal associations and their application for age, palaeoenvironmental interpretation, sequence stratigraphy, and carbonate reservoir architecture: Grzybowski Foundation Special Publication, 7, 149-165.

Husinec, A., Velić, I., Fuček, L., Vlahović, I., Matičec, D., Oštrić, N., Korbar, T., 2000, Mid Cretaceous orbitolinid (Foraminiferida) record from the islands of Cres and Lošinj (Croatia) and its regional stratigraphic correlation: Cretaceous Research, 21(1), 155-171. https://doi.org/10.1006/ cres. 2000.0203

James, G., Wynd, J., 1965, Stratigraphic nomenclature of Iranian oil consortium agreement area: American Association of Petroleum Geologists Bulletin, 49, 2182-2245. https://doi.org/10.1306/ a663388a-16c0-11d7-8645000102c1865d

Jenkyns, H.C., 2010, Geochemistry of oceanic anoxic events: Geochemistry, Geophysics, Geosystems, 11(3), Q03004. https://doi. org/10.1029/2009gc002788

Kargar, S.H., 2002, Geological Map of Saadat Shahr, scale: 1: 100000: Iran, Geological Survey of Iran.

Koop, W.J., Stoneley, R., 1982, Subsidence History of the Middle East Zagros Basin, Permian to
Recent: Philosophical Transactions of the Royal Society of London, Series A, Mathematical and Physical Sciences, 305, 149-168. https://doi. org/10.1098/rsta.1982.0031

Leckie, R.M., Bralower, T.J., Cashman, R., 2002, Oceanic anoxic events and plankton evolution: Biotic response to tectonic forcing during the mid-Cretaceous: Paleoceanography, 17(3), 10-41. https://doi. org/10.1029/2001 pa000623

Mancinelli, A., 2006, Acroporella cairensis n. sp. (Dasycladales) from the Barremian of Monte Cairo (southern Latium, Italy): Facies, 52(3), 411-416. https://doi.org/10.1007/ s10347-006-0047-3

Mansouri-Daneshvar, P., Moussavi-Harami, R., Mahboubi, A., Gharaie, M.H.M., Feizie, A., 2015, Sequence stratigraphy of the petroliferous Dariyan Formation (Aptian) in Qeshm Island and offshore (southern Iran): Petroleum Science, 12(2), 232-251. https:// doi.org/10.1007/s12182-015-0027-8

Martini, R., Cirilli, S., Saurer, C., Abate, B., Ferruzza, G., Lo Cicero, G., 2007, Depositional environment and biofacies characterization of the Triasic (Carnian to Rhaetian) carbonate succession of Punta Bassano (Marettimo Island, Sicily): Facies, 53(3), 389-400. https://doi.org/10.1007/ s10347-007-0115-3

Masse, J.P., 1993, Valanginian-early Aptian carbonate platforms from Provence, southeastern France: American Association of Petroleum Geologists Memoir, 56, 363374. https://doi.org/10.1306/M56578C29

Masse, J.P., Fenerci, M., Pernarcic, E., 2003, Palaeobathymetric reconstruction of peritidal carbonates: Late Barremian, Urgonian sequences of Provence (SE France): Palaeogeography, Palaeoclimatology, Palaeoecology, 200(1-4), 65-81. https://doi. org/10.1016/s0031-0182(03)00445-0

Maurer, F., Van Buchem, F.S.P., Eberli, G.P., Pierson, B.J., Raven, M.J., Larsen, P.H., Al-Husseini, M.I., Vincent, B., 2013, Late 
Aptian long-lived glacio-eustatic lowstand recorded on the Arabian Plate: Terra Nova, 25(2), 87-94. https://doi.org/10.1111/ ter. 12009

Mcllreath, I., James, N.P., 1984, Carbonate slopes, in Walker, R.G. (ed.), Facies Models, 2nd ed: Geoscience Canada Reprint Series, 1, 245-257.

McQuillin, H., 1974, Fahliyan Geological Compilation Map, Sheet No. 20842 W, scale 1: 100,000: Iran, Oil Survice Compony of Iran, Geological and Exploration Division.

Medvedev, A.L., Lopatin, A.Y., Masalkin, Y.V., 2011, Comparative characteristics of the lithological composition of the incised valley fill and host sediments of the Vikulovo Formation, Kamenny Area, West Siberia: Lithology and Mineral Resources, 46(4), 369-381. https://doi.org/10.1134/ s0024490211040067

Mehay, S., Keller, C.E., Bernasconi, S.M., Weissert, H., Erba, E., Bottini, C., Hochuli, P.A., 2009, A volcanic CO2 pulse triggered the Cretaceous Oceanic Anoxic Event la and a biocalcification crisis: Geology, 37(9), 819822. https://doi.org/10.1130/g30100a.1

Mehrabi, H., Rhimpour-Bonab, H., Hajikazemi, E., Esrafili-Dizaji, B., 2015, Geological reservoir characterization of the Lower Cretaceous Dariyan Formation (Shu'aiba equivalent) in the Persian Gulf, southern Iran: Marine and Petroleum Geology, 68(A), 132-157. https://doi.org/10.1016/j. marpetgeo.2015.08.014

Michalík, J., Soták, J., Lintnerová, O., Halásová, E., Bąk, M., Skupien, P., Boorová, D., 2008, The stratigraphic and paleoenvironmental setting of Aptian OAE black shale deposits in the Pieniny Klippen Belt, Slovak Western Carpathians: Cretaceous Research, 29(56), 871-892. https://doi.org/10.1016/j. cretres.2008.05.005

Moosavizadeh, M.A., Mahboubi, A., MoussaviHarami, R., Kavoosi, M.A., 2014, Early Aptian oceanic anoxic event (OAE la) in Northeastern Arabian Plate setting: an example from Dariyan Formation in Zagros fold-trust belt, SE Iran: Arabian Journal of Geosciences, 7(11), 4745-4756. https://doi. org/10.1007/s12517-013-1025-z

Motiei, H., 1993, Treatise on the Geology of Iran 1, Stratigraphy of Zagros: Tehran, Iran, Geological Survey of Iran, 536 p, (in Farsi).

Naderi-Khujin, M., Seyrafian, A., VaziriMoghaddam, H., Tavakoli, V., 2016, A record of global change: OAE 1a in Dariyan shallowwater platform carbonates, southern Tethys, Persian Gulf, Iran: Facies, 62(4), 25. https:// doi.org/10.1007/s10347-016-0476-6

Nankali, H.R., 2011, Slip rate of the Kazerun Fault and Main Recent Fault (Zagros, Iran) from 3D mechanical modelling: Journal of Asian Earth Sciences, 41(1), 89-98. https:// doi.org/10.1016/j.jseaes.2010.12.009

Navabpour, P., Angelier, J., Barrier, E., 2010, Mesozoic extensional brittle tectonics of the Arabian passive margin, inverted in the Zagros collision (Iran, interior Fars), in Leturmy, P., Robin, C. (eds.), Tectonic and Stratigraphic Evolution of Zagros and Makran during the Mesozoic-Cenozoic: Geological Society, London, Special Publications, 330: 65-96.

Nichols, G., 2009, Sedimentology and Stratigraphy: Chichester, UK, Wiley-Blackwell, 419 p.

Nissen, E., Tatar, M., Jackson, J.A., Allen, M.B., 2011, New views on earthquake faulting in the Zagros fold-and-thrust belt of Iran: Geophysical Journal International, 186(3), 928-944. https://doi. org/10.1111/j.1365-246X.2011.05119.x

Palma, R.M., Lopez-Gomez, J., Piethe, R.D., 2007, Oxfordian ramp system(La Manga Formation) in the Bardas Blancas area (Mendoza Province) Neuquén Basin, Argentina: Facies and depositional sequences: Sedimentary Geology, 195(3-4), 113-134. https://doi. org/10.1016/j.sedgeo.2006.07.001

Payros, A., Pujalte, V., 2008, Calciclastic submarine fans: An integrated overview: Earth-Science Reviews, 86(1-4), 203-246. https://doi. org/10.1016/j.earscirev.2007.09.001 
Payros, A., Pujalte, V., Tosquella, J., OrueEtxebarria, X., 2010, The Eocene stormdominated foralgal ramp of the western Pyrenees (Urbasa-Andia Formation): An analogue of future shallow-marine carbonate systems?: Sedimentary Geology, 228(34), 184-204. https://doi.org/10.1016/j. sedgeo.2010.04.010

Penney, S.J., Racey, A., 2004, Ecology of extant nummulitids and other larger benthic foraminifera: applications in palaeoenvironmental analysis: Earth-Science Reviews, 67(3-4), 219-265. https://doi. org/10.1016/j.earscirev.2004.02.005

Pérez-López, A., Pérez-Valera, F., 2012, Tempestite facies models for the epicontinental Triassic carbonates of the Betic Cordillera (southern Spain): Sedimentology, 59(2), 646-678. https://doi. org/10.1111/j.1365-3091.2011.01270.x

Piryaei,A., Reijmer,J., Borgomano,J., VanBuchem, F., 2011, Late Cretaceous tectonic and sedimentary evolution of the Bandar Abbas area, Fars region, southern Iran: Journal of Petroleum Geology, 34(2), 157-180. https:// doi.org/10.1111/j.1747-5457.2011.00499.x

Pittet,B., VanBuchem,F.S.P.,Hillgärtner,H., Razin, P., Grötsch, J., Droste, H., 2002, Ecological succession, palaeoenvironmental change, and depositional sequences of Barremian-Aptian shallow-water carbonates in northern Oman: Sedimentology, 49(3), 555-581. https://doi. org/10.1046/j.1365-3091.2002.00460.x

Pomar, L., 2001, Types of carbonate platforms: a genetic approach: Basin Research, 13(3), 313-334. https://doi. org/10.1046/j.0950-091x.2001.00152.x

Rahiminejad, A.H., Hassani, M.J., 2016a, Depositional environment of the Upper Cretaceous orbitolinidrich microfacies in the Kuh-e Mazar anticline (Kerman Province, Central Iran): Historical Biology, 28(5), 597-612. https://doi.org/10.1080/ 08912963.2014.998667

Rahiminejad, A.H., Hassani, M.J., 2016b, Paleoenvironmental distribution patterns of orbitolinids in the Lower Gretaceous deposits of eastern Rafsanjan, Central Iran: Marine Micropaleontology, 122, 53-66. https://doi. org/10.1016/j.marmicro.2015.11.006

Rahiminejad, A.H., Zand-Moghadam, H., 2018, Synsedimentary formation of ooidal ironstone: an example from the Jurassic deposits of SE central Iran: Ore Geology Reviews, 95, 238-257. https://doi. org/10.1016/j.oregeorev.2018.02.028

Rahmani, O., Aali, J., Mohseni, H., RahimpourBonab, H., Zalaghaie, S., 2010, Organic geochemistry of Gadvan and Kazhdumi formations (Gretaceous) in South Pars field, Persian Gulf, Iran:Journal of Petroleum Science and Engineering, 70(1-2), 57-66. https://doi. org/10.1016/j.petrol.2009.09.009

Rahiminejad, A.H., Yazdi, M., Ashouri, A.R., Kangazian, A., 2018, Siliciclastic input and sedimentation rate as controls on paleoecological distribution of Lower Miocene benthic carbonate producers in a fan-delta: Zagros foreland basin, Iran: Historical Biology, 30(5), 608-626. https:// doi.org/10.1080/08912963.2017.1312360

Rameil, N., Immenhauser, A., Csoma, A.É., Warrlich, G., 2012, Surfaces with a long history: the Aptian top Shu'aiba Formation unconformity, Sultanate of Oman: Sedimentology, 59(1), 212-248. https://doi. org/10.1111/j.1365-3091.2011.01279.x

Raoufian, A., Zand-Moghadam, H., SeyedEmami, K., 2019, Depositional history of Middle-Upper Jurassic succession at the Binalud mountains, NE Iran: implications of ammonite, trace fossil and stable isotopes in palaeoenvironmental analysis: Historical Biology, 1-18. https://doi.org/10.1080/089 12963.2018.1563078

Read, J.F., 1985, Carbonate platform facies models: American Association of Petroleum Geologists Bulletin, 69, 1-21.

Renema, W., Troelstra, S., 2001, Larger foraminifera distribution on a mesotrophic carbonate shelf in SW Sulawesi (Indonesia): 
Palaeogeography, Palaeoclimatology, Palaeoecology, 175, 125-146. https://doi. org/10.1016/s0031-0182(01)00389-3

Rodríguez-López, J.P., Meléndez, N., De Boer, P.L., Soria, A.R., 2008, Aeolian sand sea development along the midCretaceous western Tethyan margin (Spain): erg sedimentology and palaeoclimate implications: Sedimentology, 55(5), 1253-1292. https://doi. org/10.1111/j.1365-3091.2007.00945.x

Romero, J., Caus, E., Rosell, J., 2002, A model for the palaeoenvironmental distribution of larger foraminifera based on late Middle Eocene deposits on the margin of the South Pyrenean basin (NE Spain): Palaeogeography, Palaeoclimatology, Palaeoecology, 179(12), 43-56. https://doi.org/10.1016/ s0031-0182(01)00406-0

Rubert, Y., Jati, M., Loisy, C., Cerepi, A., Foto, G., Muska, K., 2012, Sedimentology of resedimented carbonates: Facies and geometrical characterisation of an upper Cretaceous calciturbidite system in Albania: Sedimentary Geology, 257, 63-77. https:// doi.org/10.1016/j.sedgeo.2012.02.009

Safaei, H., 2009, The continuation of the Kazerun fault system across the Sanandaj-irjan zone (Iran): Journal of Asian Earth Sciences, 35(5), 391-400. https://doi.org/10.1016/j. jseaes.2009.01.007

Sahagian, D., Pinous, O., Olferiev, A., Zakharov, V., 1996, Eustatic curve for the Middle Jurassic-Cretaceous based on Russian platform and Siberian stratigraphy: zonal resolution: American Association of Petroleum Geologists Bulletin, 80, 14331458. https://doi.org/10.1306/64ed9a561724-11d7-8645000102c1865d

Sandulli, R., Raspini, A., 2004, Regional to global correlation of lower Cretaceous (Hauterivian-Barremian) shallow-water carbonates of the southern Apennines (Italy) and Dinarides (Montenegro), Southern Tethyan Margin: Sedimentary
Geology, 165(1-2), 117-153. https://doi. org/10.1016/j.sedgeo.2003.11.014

Schroeder, R., Van Buchem, F.S.P., Cherchi, A., Baghbani, D., Vincent, B., Immenhauser, A., Granier, B., 2010, Revised orbitolinid biostratigraphic zonation for the BarremianAptian of the eastern Arabian Plate and implications for regional stratigraphic correlations: GeoArabia, Special Publication, 4(1), 49-96.

Sepehr, M., Cosgrove, J.W., 2004, Structural framework of the Zagros Fold-Thrust Belt, Iran: Marine and Petroleum Geology, 21, 829-843.

Setudehnia,A., 1978, The MesozoicsequenceinsouthwestIranandadjacentareas:Journalof Petroleum Geology, 1, 3-42. https://doi.org/10.1306/ bf9ab591-0eb6-11d7-8643000102c1865d

Sedaghat, R., 1982, The sedimentology of the Upper Khami Group, Lower Cretaceous, in East Khuzestan, Southwest Iran: London, UK, University of London, Ph.D. thesis.

Sharland, P.R., Archer, R., Casey, D.M., Davies, R.B., Hall, S.H., Heward, A.P., Horbury, A.D., Simmons, M.D., 2001, Arabian Plate sequence stratigraphy: GeoArabia, Special Publication, 2, $371 \mathrm{p}$.

Skelton, P.W., Gili, E., 2012, Rudists and carbonate platforms in the Aptian: a case study on biotic interactions with ocean chemistry and climate: Sedimentology, 59(1), 81-117. https://doi. org/10.1111/j.1365-3091.2011.01292.x

Skelton, P.W., Spicer, R.A., Kelley, S.P., Gilmour, I., 2003, The Cretaceous world: New York, U.S.A., Cambridge University Press, 360 p.

Stein, M., Westermann, S., Adatte, T., Matera, V., Fleitmann, D., Spangenberg, J.E., Föllmi, KB., 2012, Late Barremiane Early Aptian palaeoenvironmental change: The CassisLa Bédoule section, southeast France: Cretaceous Research, 37, 209-222. https:// doi.org/10.1016/j.cretres.2012.03.021

Strasser, A., Samankassou, E., 2003, Carbonate Sedimentation Rates Today and in the Past: Holocene of Florida Bay, Bahamas, and Bermuda vs. Upper Jurassic and Lower 
Cretaceous of the Jura Mountains (Switzerland and France): Geologia Croatica, 56(1), 1-18.

Talbot, C.J., Alavi, M., 1996, The past of a future syntaxis across the Zagros: Geological Society, London, Special Publications, 100, 89-110.

Tavakoli, F., Walpersdorf, A., Authemayou, C., Nankali, H.R., Hatzfeld, D., Tatar, M., Djamour, Y., Nilforoushan, F., Cotte, N., 2008, Distribution of the right-lateral strikeslip motion from the Main Recent Fault to the Kazerun Fault System (Zagros, Iran): Evidence from present-day GPS velocities: Earth and Planetary Science Letters, 275(3-4), 342-347. https://doi.org/10.1016/j.epsl.2008.08.030

Van Buchem, F.S.P., Pittet, B., Hillgärtner, H., Grötsch,J., Al-Mansouri,A., Billing, I., Droste, H.J., Oterdoom, H., 2002, High-resolution Sequence-stratigraphic Architecture of Barremian/Aptian Carbonate Systems in northern Oman and the United Arab Emirates (Kharaib and Shuaiba Formations): GeoArabia, 7(3), 461-500.

Van Buchem, F.S.P., Baghbani, D., Bulot, L.G., Caron, M., Gaumet, F., Hosseini, S., Keyvani, F., Schroeder, R., Swennen, R., Vedrenne, V., Vincent, B., 2010, Barremian-Lower Albian sequence-stratigraphy of southwest Iran (Gadvan, Dariyan and Kazhdumi formations) and its comparison with Oman, Qatar and the United Arab Emirates, in Van Buchem, F.S.P., Al-Husseini, M.I., Maurer, F., Droste, H.J. (eds.), Barremian-Aptian Stratigraphy and Hydrocarbon Habitat of the Eastern Arabian Plate, Vol. 2: Gulf Petro Link, Bahrain, GeoArabia Special Publications 4, 503-548.

Vaziri-Moghaddam, H., Kimiagari, M., Taheri, A., 2006, Depositional environment and sequence stratigraphy of the Oligo-Miocene Asmari Formation in SW Iran: Facies, 52(1), 41-51. https://doi.org/10.1007/ s10347-005-0018-0

Weissert, H., Erba, E., 2004, Volcanism, CO2 and palaeoclimate: a Late JurassicEarly Cretaceous carbon and oxygen isotope record: Journal of the Geological Society, 161(4), 695-702. https://doi. org/10.1144/0016-764903-087

Wilmsen, M., Fürsich, F.T., Seyed-Emami, K., Majidifard, M.R., Zamani-Pedram, M., 2010, Facies analysis of a large-scale Jurassic shelf-lagoon: the Kamar-e-Mehdi Formation of east-central Iran: Facies, 56(1), 59-87. https://doi.org/10.1007/ s10347-009-0190-8

Wilson, J.L., 1975, Carbonate Facies in Geologic History: Berlin, Heidelberg, New York, Springer-Verlag, $471 \mathrm{p}$.

Witt, W., Gökdag, H., 1994, Orbitolinid biostratigraphy of the Shu'aiba Formation (Aptian), Oman - implications for reservoir development, in Simmons, M.D. (ed.), Micropalaeontology and Hydrocarbon Exploration in the Middle East: London/ New York, Chapman and Hall, 221-234.

Wynd, J.G., 1965, Biofacies of the Iranian oil consortium agreement area: Tehran, Iran, Iranian Oil Operating Companies, Geological and Exploration Division, Report No. 1082.

Yousefi, T., Kargar, S., 1999, Geological Compilation Map of Sivand, scale 1: 100000: Tehran, Iran, Geological Survey of Iran.

Ziegler, M.A., 2001, Late Permian to Holocene paleofacies evolution of the Arabian Plate and its hydrocarbon occurrences: GeoArabia, $6,445-504$. 